\title{
Financial Integration in Asia: Recent Developments and Next Steps
}

David Cowen, Ranil Salgado, Hemant Shah, Leslie Teo, and Alessandro Zanello 



\title{
IMF Working Paper
}

Asia and Pacific Department

\section{Financial Integration in Asia: Recent Developments and Next Steps \\ Prepared by David Cowen, Ranil Salgado, Hemant Shah, Leslie Teo, and Alessandro Zanello ${ }^{1}$}

Authorized for distribution by Daniel Citrin

August 2006

\begin{abstract}

\section{This Working Paper should not be reported as representing the views of the IMF.} The views expressed in this Working Paper are those of the author(s) and do not necessarily represent those of the IMF or IMF policy. Working Papers describe research in progress by the author(s) and are published to elicit comments and to further debate.
\end{abstract}

This Working Paper brings together three papers prepared as background for discussions at the Second High-Level Conference on Asian Integration cohosted by the Monetary Authority of Singapore and the IMF on May 25, 2006. The first documents recent trends in the intraregional flow of goods and capital and explores linkages between real and financial integration. The second focuses on the institutional and regulatory reforms needed to reap the benefits - and contain the risks - of financial integration in Asia. The third considers the implications of economic integration for the choice of the exchange rate regime and the conduct of macroeconomic policies.

JEL Classification Numbers: F15, F30, G15, G20, D53

Keywords: Globalization, Regional Integration, Asia

Author(s) E-Mail Address: dcowen@imf.org, rsalgado@imf.org, hshah@imf.org, 1teo@imf.org, azanello@imf.org

\footnotetext{
${ }^{1}$ Brian Bell, Mali Chivakul, Robert Flood, Akito Matsumoto, and Yuji Yokoburi also contributed to this paper.
} 
I. Globalization of Production and Financial Integration in Asia .........................................4

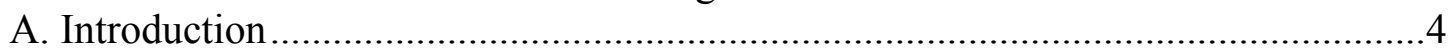

B. Intraregional Trade Flows and Production Linkages .......................................

C. Intraregional Financial Flows.................................................................... 8

D. Intraregional Trade and Financial Integration: The Linkages ...............................11

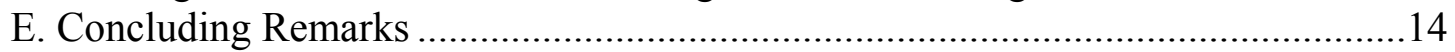

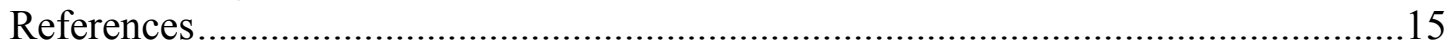

Tables

I.1 Trade Openness .........................................................................................

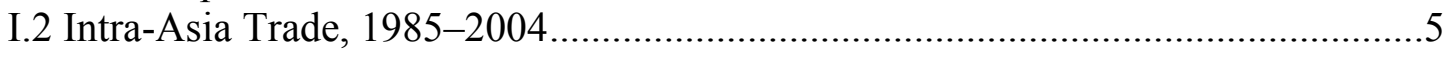

I.3 Share of Trade Growth Attributable to Sub-Regions and Rest of World................6

I.4 Intra-Industry Trade in the EU and Emerging Asia .........................................

I.5 Intra-ASEAN Trade................................................................................ 7

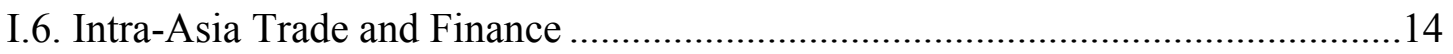

Figures

I.1. Net Private Capital Flows to Emerging Markets................................................

I.2. Asia's Foreign Portfolio Assets and Liabilities, by Type.....................................

I.3. Asia's Foreign Portfolio Liabilities, by Origin...................................................... 9

I.4. EU15's Foreign Portfolio Liabilities, by Origin................................................ 9

I.5. Asia's Foreign Portfolio Assets, by Region .................................................. 9

I.6. EU15's Foreign Portfolio Assets, by Region ....................................................9

I.7. Asian Banks' Foreign Claims, by Region ........................................................ 10

I.8. Foreign Banks' Claims on Asia, by Origin ...................................................... 10

I.9. Foreign Banks' Claims on ASEAN, by Origin ............................................... 10

I.10. Foreign Banks' Foreign Claims on EU15, by Origin......................................10

II. Role of Institutions and Markets to Foster Financial Integration

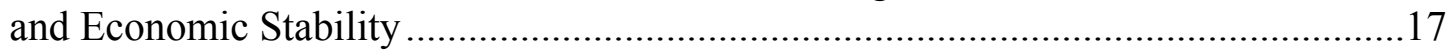

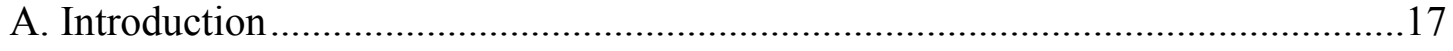

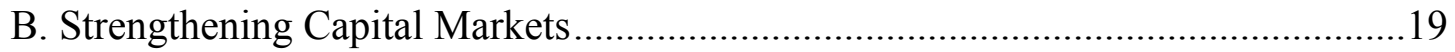

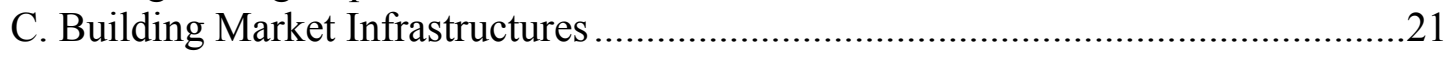

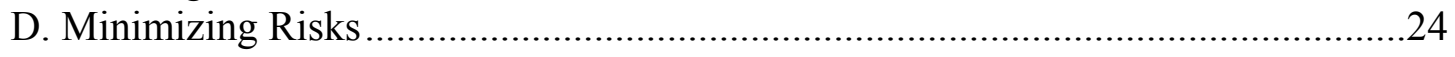

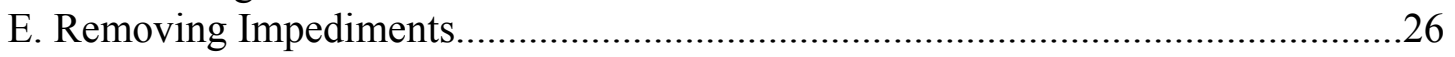

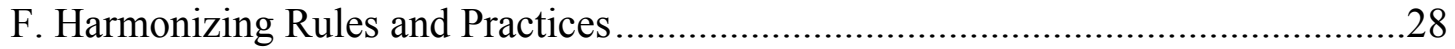

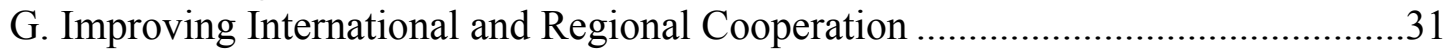

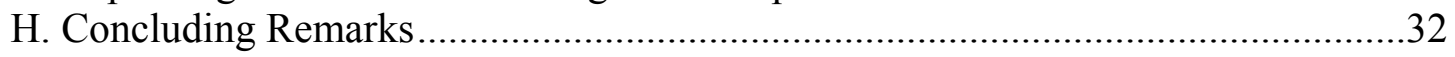

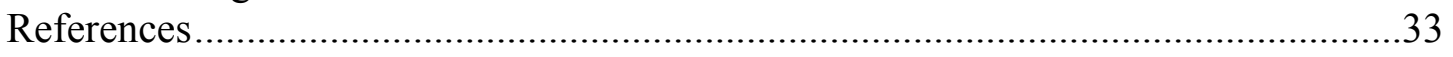

Tables

II.1. Pension Fund Portfolio Allocation.................................................................. 19

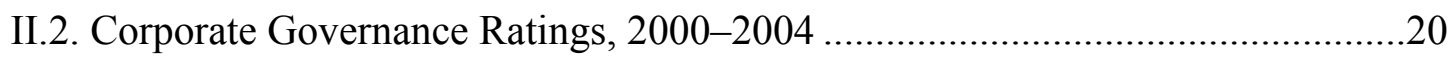

II.3. Examples of Local Financial Conglomerates, Selected Asian Countries ............25 
II.4. Major Financial Groups with Cross-Border Presence, Selected Asian Countries26

Figures

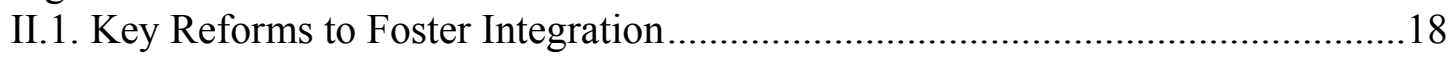

II.2. Government Bonds Annual Turnover Ratios in 2005 ....................................22

Appendix

II.1. Key Financial Market Indicators. .34

II.2. Regulations on Cross-Border Portfolio Investments, Selected Asian Countries .36

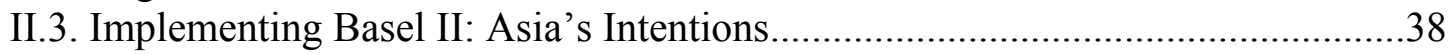

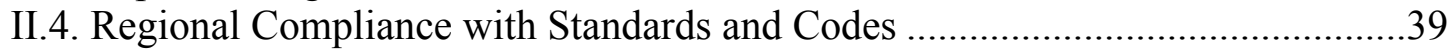

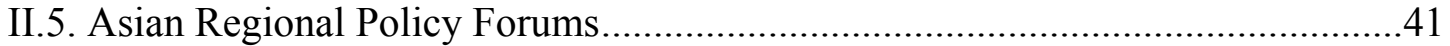

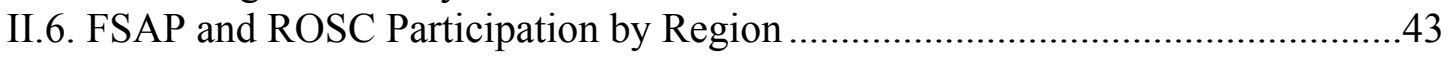

III. Regional Integration and Macroeconomic Policies ....................................................44

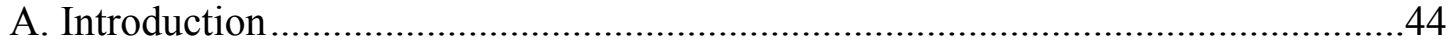

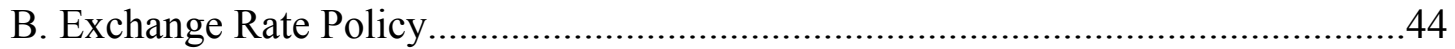

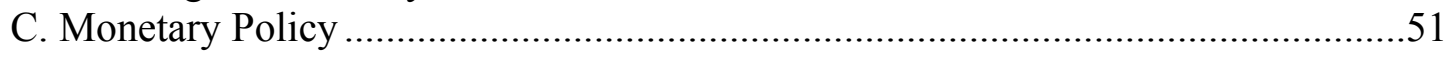

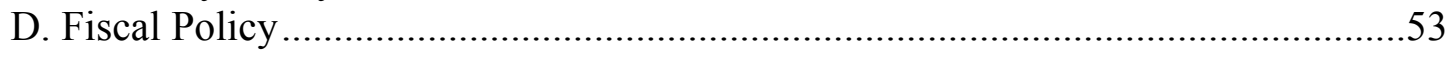

E. Integration and Macro Policies in the Long Run..............................................54

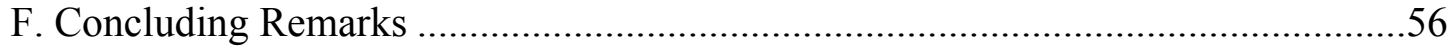

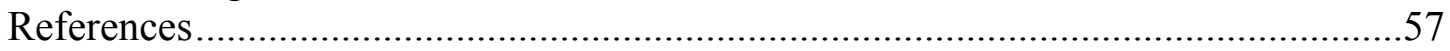

Tables

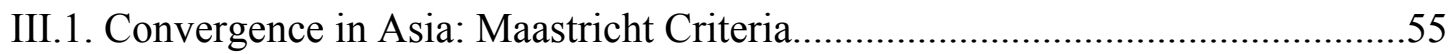

Figures

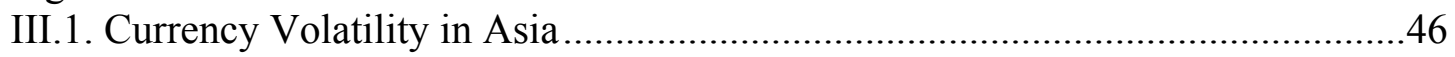

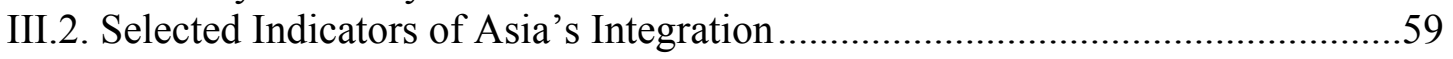




\section{Globalization of Production and Financial Integration in Asia ${ }^{2}$}

\section{A. Introduction}

Over the years, Asian economies have depended heavily on global and regional trade. Asian trade growth in the past two decades, in fact, has outperformed regional GDP as well as global trade in all broad forms - goods, services, exports, or imports - averaging over $10 \frac{1}{2}$ percent a year (in U.S. dollar terms). ${ }^{3}$ As a result, the region's share of world trade has risen substantially. In addition, trade openness, as measured by the ratio of goods and services trade to GDP, has increased in nearly all countries in the region and, on average, is higher than in most other regions of the world. Intraregional trade has grown even faster, roughly doubling as a share of GDP over the same period. In recent years, this has been spurred by vertical integration of production networks and supply chains, especially reflecting the integration of China with the rest of the region and the world.

\begin{tabular}{|c|c|c|c|c|c|c|}
\hline \multicolumn{7}{|c|}{$\begin{array}{l}\text { Table I.1.Trade Openness } \\
\text { (In percent of GDP) }\end{array}$} \\
\hline & \multicolumn{2}{|c|}{ Exports } & \multicolumn{2}{|c|}{ Imports } & \multicolumn{2}{|c|}{ Total Trade } \\
\hline & 1990 & 2005 & 1990 & 2005 & 1990 & 2005 \\
\hline U.S. & 9.2 & 10.2 & 10.6 & 16.0 & 19.8 & 26.2 \\
\hline Euro Zone & 27.9 & 37.6 & 27.6 & 36.1 & 55.5 & 73.7 \\
\hline Japan & 10.6 & 14.8 & 9.8 & 13.3 & 20.4 & 28.1 \\
\hline Emerging South America & 24.8 & 30.7 & 18.8 & 26.7 & 43.6 & 57.4 \\
\hline China & 14.8 & 37.9 & 12.0 & 32.2 & 26.8 & 70.0 \\
\hline India & 7.2 & 20.5 & 9.3 & 25.3 & 16.4 & 45.8 \\
\hline Indonesia & 23.8 & 38.1 & 24.4 & 34.3 & 48.2 & 72.4 \\
\hline Korea Rep. of & 27.8 & 42.2 & 28.9 & 39.6 & 56.7 & 81.8 \\
\hline Malaysia & 74.6 & 121.9 & 72.6 & 98.4 & 147.2 & 220.3 \\
\hline Philippines & 25.9 & 45.2 & 31.6 & 53.1 & 57.5 & 98.3 \\
\hline Thailand & 36.6 & 76.2 & 45.2 & 78.3 & 81.8 & 154.5 \\
\hline Vietnam & 32.6 & 71.5 & 30.9 & 79.8 & 63.6 & 151.3 \\
\hline
\end{tabular}

By contrast, financial integration has been more sluggish, particularly regionally. As discussed in the last high-level seminar, Asia's financial integration with the world is well advanced by some measures, including net private capital flows, foreign participation in some markets, and stock market correlations (IMF, 2005b). By other measures, however, the picture is mixed. For example, total financial liabilities in Asia (the combined stock of foreign direct investment (FDI), foreign loans, and equity holdings) is typically lower than in other regions of the world. Moreover, intraregional financial integration - for example, measured directly by cross-border capital flows or indirectly by cross-border correlation of consumption growth-has been more limited than elsewhere. Consequently, Asian economies appear to have become more integrated with countries outside the region than within the region. At the same time, the region generates substantial net saving (that is, domestic saving exceeds domestic investment), and countries have been accumulating large stocks of foreign reserves. This has resulted in the financial sectors of developed countries in Europe and North America serving as financial intermediaries for the Asian economies, with relatively more stable outbound official flows and more volatile inbound private flows.

\footnotetext{
${ }^{2}$ Prepared by David Cowen and Ranil Salgado.

${ }^{3}$ In this paper, the Asia region refers to Australia, China, India, Hong Kong SAR, Japan, the Republic of Korea, New Zealand, Taiwan Province of China, and the 10 Association of Southeast Asian Nations (ASEAN) countries. Industrial Asia refers to Australia, Japan, and New Zealand. Emerging Asia refers to the newly industrialized economies (the Republic of Korea, Hong Kong SAR, Singapore, and Taiwan Province of China), as well as China, India, and the ASEAN-4 (Indonesia, Malaysia, the Philippines, and Thailand).
} 
The main aim of this paper is to document recent trends and patterns in trade and financial integration at the regional level and explore potential linkages, or the lack thereof, between the two. The analysis is complicated by limited bilateral data on cross-border financial flows, as well as nonfactor services. As such, the paper is primarily descriptive. In Section B, the paper briefly depicts recent patterns in bilateral trade. Section $\mathrm{C}$ gives an overview of some measures of intraregional financial integration, including portfolio flows (both equity and debt securities) and bank borrowing and lending, as well as comovements in financial markets. In Section D, the paper examines possible linkages between the real and financial integration, including by reviewing studies of other regions, particularly Europe. Section E has some concluding remarks.

\section{B. Intraregional Trade Flows and Production Linkages}

The rise in intraregional trade flows in Asia has been a hallmark of the region's rapid growth and greater interdependency over the past two decades. Among the major economies in the region, intraregional exports (as a share of total exports) rose from an average of 44 percent during 1985-91 to 52 percent during 1999-2004. The overall rise has been particularly dramatic for the Republic of Korea and Taiwan Province of China, with sizable increases also for Japan, Singapore, and the Philippines. Intraregional imports also increased (as a share of total imports) from 46 percent to 49 percent over the same period. The major exception to these trends is China. There, both the share of exports and imports in the region fell, although China's import intensity in Asia during 1999-2004 remained above the group average.

Table I.2.

\begin{tabular}{|c|c|c|c|c|c|c|c|c|c|c|c|c|}
\hline \multicolumn{13}{|c|}{ Intra-Asia Trade, 1985-2004 1/ 2/ } \\
\hline & \multicolumn{3}{|c|}{$1985-91 \quad 1992-98 \quad 1999-2004$} & \multicolumn{3}{|c|}{ 1985-91 1992-98 1999-2004 } & \multicolumn{3}{|c|}{ 1985-91 1992-98 1999-2004 } & \multicolumn{3}{|c|}{$1985-91 \quad 1992-98 \quad 1999-2004$} \\
\hline & \multirow{2}{*}{\multicolumn{3}{|c|}{$\begin{array}{l}\text { Exports to Asia } \\
\text { (In percent of total }\end{array}$}} & \multirow{2}{*}{\multicolumn{3}{|c|}{$\begin{array}{l}\text { Imports from Asia } \\
1 \text { export or imports) }\end{array}$}} & \multirow{2}{*}{\multicolumn{3}{|c|}{$\begin{array}{r}\text { Exports to Asia } \\
\text { (In per }\end{array}$}} & \multicolumn{3}{|c|}{ Imports from Asia } \\
\hline & & & & & & & & & & f own GDI & & \\
\hline \multicolumn{13}{|l|}{ Industrial Asia } \\
\hline Japan & 32.0 & 41.9 & 45.1 & 26.2 & 30.7 & 38.3 & 3.2 & 3.8 & 4.8 & 2.6 & 2.8 & 4.1 \\
\hline Australia & 60.3 & 68.8 & 65.2 & 42.5 & 45.9 & 51.0 & 7.6 & 9.8 & 9.8 & 6.0 & 7.4 & 9.3 \\
\hline New Zealand & 51.8 & 59.9 & 57.9 & 48.7 & 53.0 & 61.9 & 11.3 & 13.4 & 13.2 & 10.6 & 11.8 & 14.1 \\
\hline \multicolumn{13}{|l|}{ Emerging Asia } \\
\hline \multicolumn{13}{|l|}{ Newly industrialized economies } \\
\hline Korea & 18.0 & 36.9 & 41.5 & 17.5 & 24.6 & 30.3 & 5.1 & 9.9 & 13.6 & 5.0 & 6.5 & 9.9 \\
\hline Hong Kong SAR & 47.0 & 53.0 & 57.5 & 75.1 & 83.4 & 84.4 & 47.2 & 59.4 & 73.5 & 75.3 & 93.4 & 107.2 \\
\hline Singapore & 53.8 & 58.8 & 63.8 & 63.2 & 62.3 & 55.9 & 75.3 & 78.4 & 95.3 & 88.5 & 82.9 & 83.2 \\
\hline Taiwan Province of China & 35.3 & 50.3 & 56.7 & 34.8 & 47.0 & 53.8 & 16.0 & 19.6 & 26.2 & 15.8 & 18.3 & 24.8 \\
\hline \multicolumn{13}{|l|}{ Other emerging economies } \\
\hline China & 64.8 & 59.2 & 50.1 & 61.4 & 54.2 & 52.4 & 8.4 & 11.0 & 11.5 & 7.6 & 10.0 & 12.2 \\
\hline India & 24.7 & 28.9 & 28.7 & 32.4 & 27.2 & 33.2 & 1.2 & 2.3 & 2.8 & 1.5 & 2.2 & 3.3 \\
\hline Indonesia & 67.5 & 62.9 & 64.4 & 40.4 & 42.9 & 33.2 & 12.9 & 15.4 & 19.9 & 7.8 & 10.1 & 10.2 \\
\hline Malaysia & 44.7 & 48.0 & 50.4 & 33.4 & 39.0 & 40.7 & 26.7 & 38.3 & 52.2 & 20.1 & 31.0 & 42.1 \\
\hline Philippines & 23.2 & 27.1 & 43.0 & 49.0 & 55.6 & 45.7 & 4.1 & 7.3 & 20.0 & 8.6 & 14.2 & 21.3 \\
\hline Thailand & 43.3 & 50.4 & 54.3 & 72.6 & 68.6 & 56.3 & 10.6 & 17.8 & 30.0 & 18.1 & 23.5 & 31.1 \\
\hline Average (unweighted) & 43.6 & 49.7 & 52.2 & 45.9 & 48.8 & 49.0 & 17.7 & 22.0 & 28.7 & 20.6 & 24.2 & 28.7 \\
\hline
\end{tabular}

On both the export and import side, the rise in intraregional trade has brought a shift in trade patterns, most dramatically for the newly industrialized economies (NIEs), which have seen 
trade among themselves and with industrial Asia shift to other parts of emerging Asia (especially China). The major exception is Singapore, where exports to other NIEs and industrial Asia continue to be driving forces in its intraregional trade. China itself has also seen a rise in the share of trade growth (both exports and imports) attributable to emerging Asia, but this has been overshadowed by larger falls in shares of industrial Asia and the NIEs, leading to some moderate reduction in the relative importance of the region as a whole to China's trade.

Table I.3.

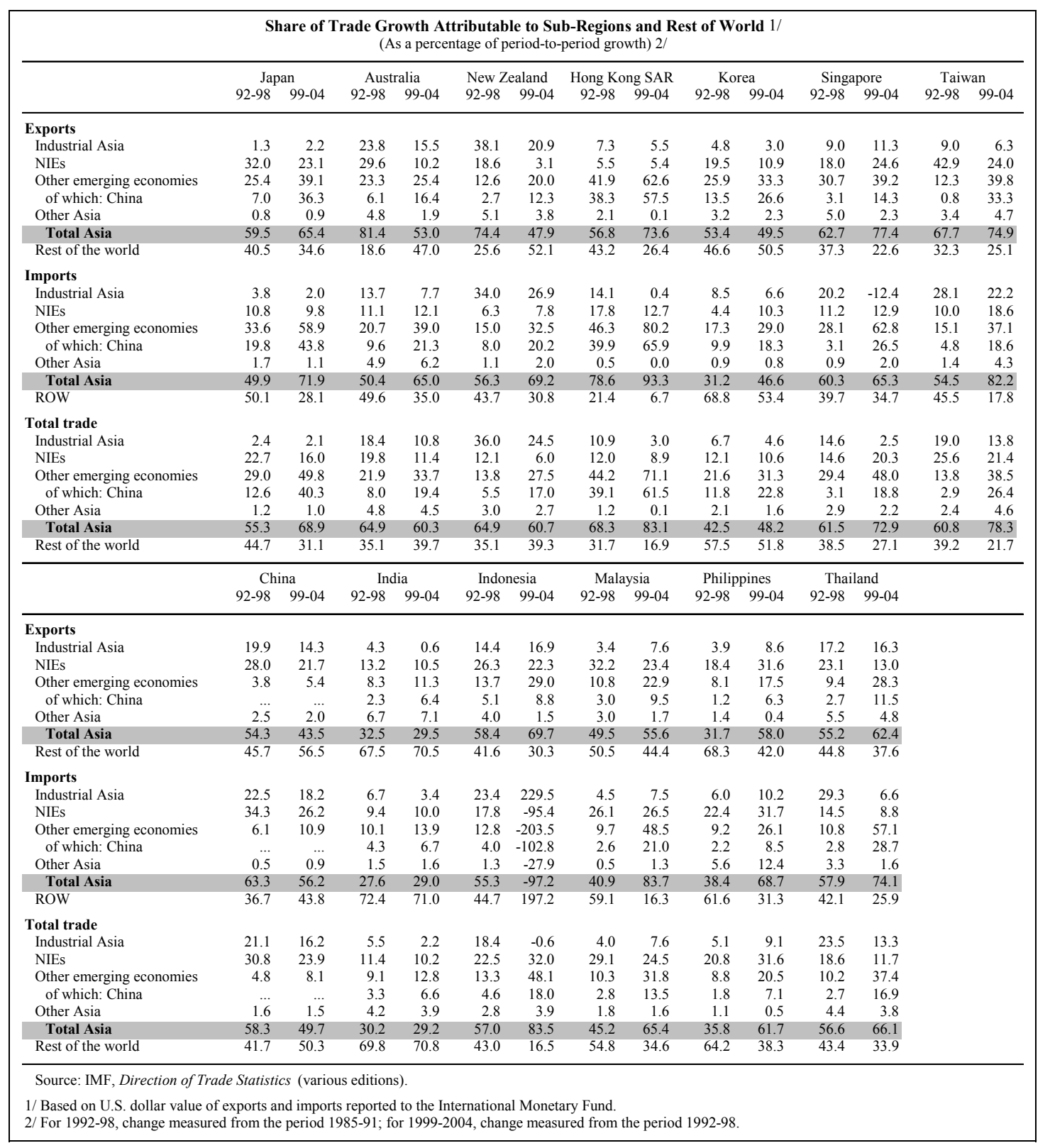

Growth in intra-Asia trade has been driven primarily by growth in intra-industry trade, as noted in the IMF's Asia-Pacific Regional Outlook (2005a). This change largely resulted from vertical specialization in output and production relocation across borders in Asia, with much of the growth coming in the export of intermediate goods to ultimately feed global demand (Fukao et 
al., 2003; and MAS, 2005). It contrasts with the European Union (EU), where the growth in intra-industry trade has been driven more by horizontal rather than vertical product differentiation and concentrated on the export of final goods for domestic demand. China's emergence as a processing giant has been key to these developments, causing a sizeable shift in regional trade pattern (see Zhang et al.,

\begin{tabular}{|c|c|c|c|c|}
\hline \multicolumn{5}{|c|}{$\begin{array}{l}\text { Table I.4. Intra-industry Trade (IIT) in the EU and Emerging Asia } \\
\text { (In percent of total trade) }\end{array}$} \\
\hline & \multicolumn{2}{|c|}{ Emerging Asia } & \multicolumn{2}{|c|}{ European Union } \\
\hline & Horizontal IIT & Vertical IIT & Horizontal IIT & Vertical IIT \\
\hline 1996 & 4.7 & 16.6 & 28.5 & 37.5 \\
\hline 1997 & 6.1 & 17.8 & 26.1 & 38.9 \\
\hline 1998 & 5.1 & 20.0 & 26.5 & 40.0 \\
\hline 1999 & 5.1 & 24.6 & 26.2 & 40.6 \\
\hline 2000 & 7.6 & 23.7 & 25.8 & 40.0 \\
\hline
\end{tabular}

2005). ${ }^{4}$ However, over time, some movement is expected towards horizontal integration, as China's economy further develops and production moves up the supply chain, bringing another possible realignment in regional trade. Consistent with vertical specialization, China has become a significantly larger factor in explaining the rise in intraregional trade for industrial Asia and the NIEs (except Singapore). The same holds for emerging and developing Asia economies, which on the one hand may be in direct competition for the processing trade and/or have similar factor endowments to China, but on the other have become important suppliers of primary and secondary inputs.

The evidence is less clear whether the growth in intraregional trade has been aided by trading blocs. $\mathrm{Ng}$ and Yeats (2003) and Abraham and Van Hove (2005) find that ASEAN has played only a minor role in expanding intraEast Asian trade (although the latter's findings suggest that China's entrance into ASEAN could give intra-group trade a major boost and attract FDI into group economies). Focusing on the ASEAN-5, the importance of intra-group trade (vis-à-vis Asia as a whole) has only increased moderately in the past 20 years (actually declining for Malaysia).

Consistent with this

\begin{tabular}{|c|c|c|c|c|c|c|}
\hline \multicolumn{7}{|c|}{ Table I.5. Intra-ASEAN Trade 1/ } \\
\hline & $1985-91$ & 1992-98 & $1999-2005$ & $1985-91$ & $1992-98$ & 1999-2005 \\
\hline & \multicolumn{3}{|c|}{ Exports to ASEAN-5 } & \multicolumn{3}{|c|}{ Imports from ASEAN-5 } \\
\hline & \multicolumn{6}{|c|}{ (In percent of own GDP) } \\
\hline Indonesia & 2.0 & 3.7 & 5.1 & 1.4 & 2.2 & 3.3 \\
\hline Malaysia & 15.2 & 21.2 & 24.9 & 10.3 & 15.2 & 19.5 \\
\hline Philippines & 1.4 & 2.8 & 7.2 & 2.3 & 4.2 & 7.2 \\
\hline Singapore & 33.2 & 34.8 & 39.2 & 34.0 & 35.8 & 38.9 \\
\hline \multirow[t]{2}{*}{ Thailand } & 3.3 & 6.4 & 9.9 & 5.0 & 6.5 & 8.7 \\
\hline & \multicolumn{6}{|c|}{ (In percent of Asia total exports or imports) } \\
\hline Indonesia & 18.5 & 20.9 & 33.0 & 15.5 & 23.0 & 25.6 \\
\hline Malaysia & 51.5 & 49.0 & 46.3 & 56.9 & 55.7 & 47.7 \\
\hline Philippines & 26.3 & 29.3 & 33.9 & 34.0 & 37.5 & 36.1 \\
\hline Singapore & 38.5 & 43.2 & 46.8 & 44.2 & 44.3 & 41.2 \\
\hline \multirow[t]{2}{*}{ Thailand } & 27.6 & 27.7 & 28.1 & 31.4 & 36.2 & 33.0 \\
\hline & \multicolumn{6}{|c|}{ (In percent of global total exports or imports) } \\
\hline Indonesia & 7.5 & 9.0 & 11.0 & 10.4 & 14.4 & 16.5 \\
\hline Malaysia & 17.2 & 19.1 & 18.8 & 25.4 & 26.7 & 24.0 \\
\hline Philippines & 12.9 & 16.3 & 15.5 & 7.9 & 10.2 & 15.5 \\
\hline Singapore & 24.3 & 26.9 & 26.2 & 23.8 & 26.1 & 26.3 \\
\hline Thailand & 20.0 & 19.0 & 15.8 & 13.6 & 18.2 & 17.9 \\
\hline \multicolumn{7}{|c|}{ Source: IMF, Direction of Trade Statistics (various editions). } \\
\hline 1/ ASEAN & ndonesi & a, Malays & he Phil & Singapo & nd Th & nd). \\
\hline
\end{tabular}

\footnotetext{
${ }^{4}$ For the 12 Asia-Pacific economies examined in Zhang et al. (2005), about three-quarters of the increase in total intra-industry trade (IIT) with China can be explained by vertical IIT during 1999-2001. This finding is consistent with results for emerging Asia in Fukao et al. (2003), who find on average that 78 percent of the rise in total IIT in the region during 1996-2000 is due to vertical ITT.
} 
observation, the IMF's Asia and Pacific Regional Economic Outlook (2006) notes that members of regional trade agreements (RTAs), especially ASEAN, have a high degree of openness with non-members in the Asia region (compared with RTAs outside Asia), explaining their relative importance to trade growth. A main reason cited for this difference is that regional trade integration in Asia followed a long period of unilateral liberalization in the 1980s and 1990 s, with regional integration paralleling multilateral liberalization in a number of countries, all conducive to trade creation.

\section{Intraregional Financial Flows}

Standard measures of financial integration indicate that inter-regional integration continues to dominate intraregional integration. Financial integration is measured using a number of approaches in the economic literature. Generally, these are divided into three categories: quantity-based measures, price-based measures, and institutional/regulatory measures. This section examines evidence on the first two categories of measures, including by examining recent trends in cross-border financial flows and stocks and co-movements of interest rates, bond yields, and stock prices. As noted above, bilateral financial flows and stock data are limited, with gaps in both time and country coverage, thus complicating the assessment of financial integration at a regional level. Additionally, price co-movements could reflect common factors and/or similarities in fundamentals, rather than the degree of integration.

Indirect measures also suggest limited regional financial integration in Asia. Financial integration allows countries to diversify asset holdings and, in theory, sources of income, and thus shift income risks to other parts of the region or world. This suggests that the volatility of consumption relative to income should decrease with increasing financial integration, and also that consumption patterns should be more correlated across countries that are more integrated. However, empirical studies (such as Mercereau, 2005) find that consumption growth in most Asian countries has a low or negative correlation with that in other Asian countries. This compares with a correlation of about 0.6 among Euro area countries.

In terms of overall financial flows, Asia has benefited from the surge in net capital flows to emerging markets in recent years, with the stock of foreign investment in Asia increasing substantially. The region received roughly a half of the global supply of net private capital flows during 2003-2004, although the pace of inflows slowed in 2005. Indeed, based on the IMF's Coordinated Portfolio Investment (CPIF), Asia's foreign portfolio investment liabilities rose by 91 percent during 2001-2004 to US\$1.9 trillion (8 percent of the global total or 19 percent of Asia's GDP), with equity securities increasing at a faster rate than debt securities and reaching almost two-thirds of the total.

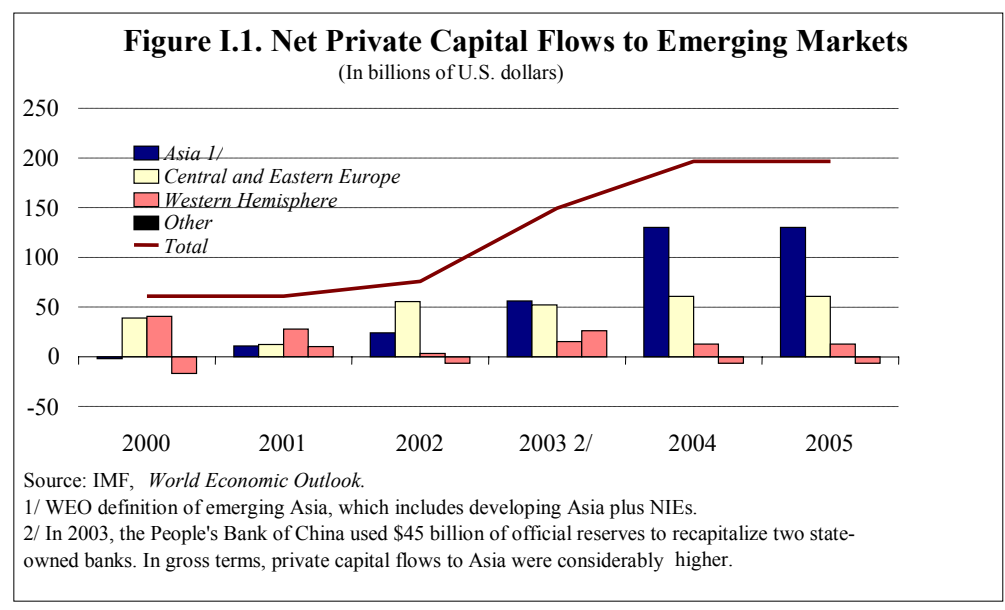


During the same period, Asia has also become a major portfolio investor in global markets. Based on the CPIF, Asia's cross-border portfolio investment assets increased by 66 percent to US\$2.8 trillion (over 12 percent of the global total or 29 percent of Asia's GDP) during 20012004. In terms of composition of the flows, Asia's stock of equity securities increased at a faster rate than of debt securities, but

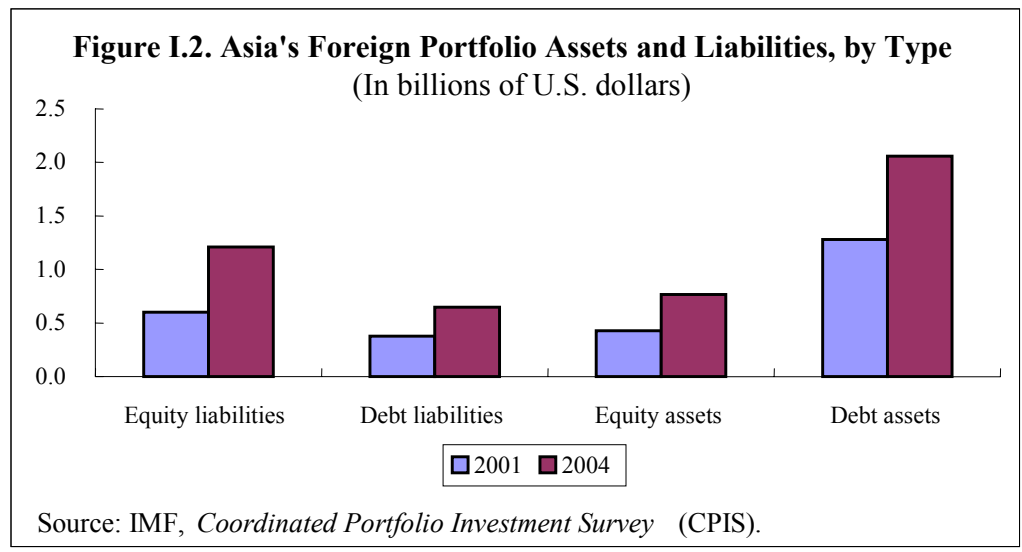
still amount to only about a quarter of the total.
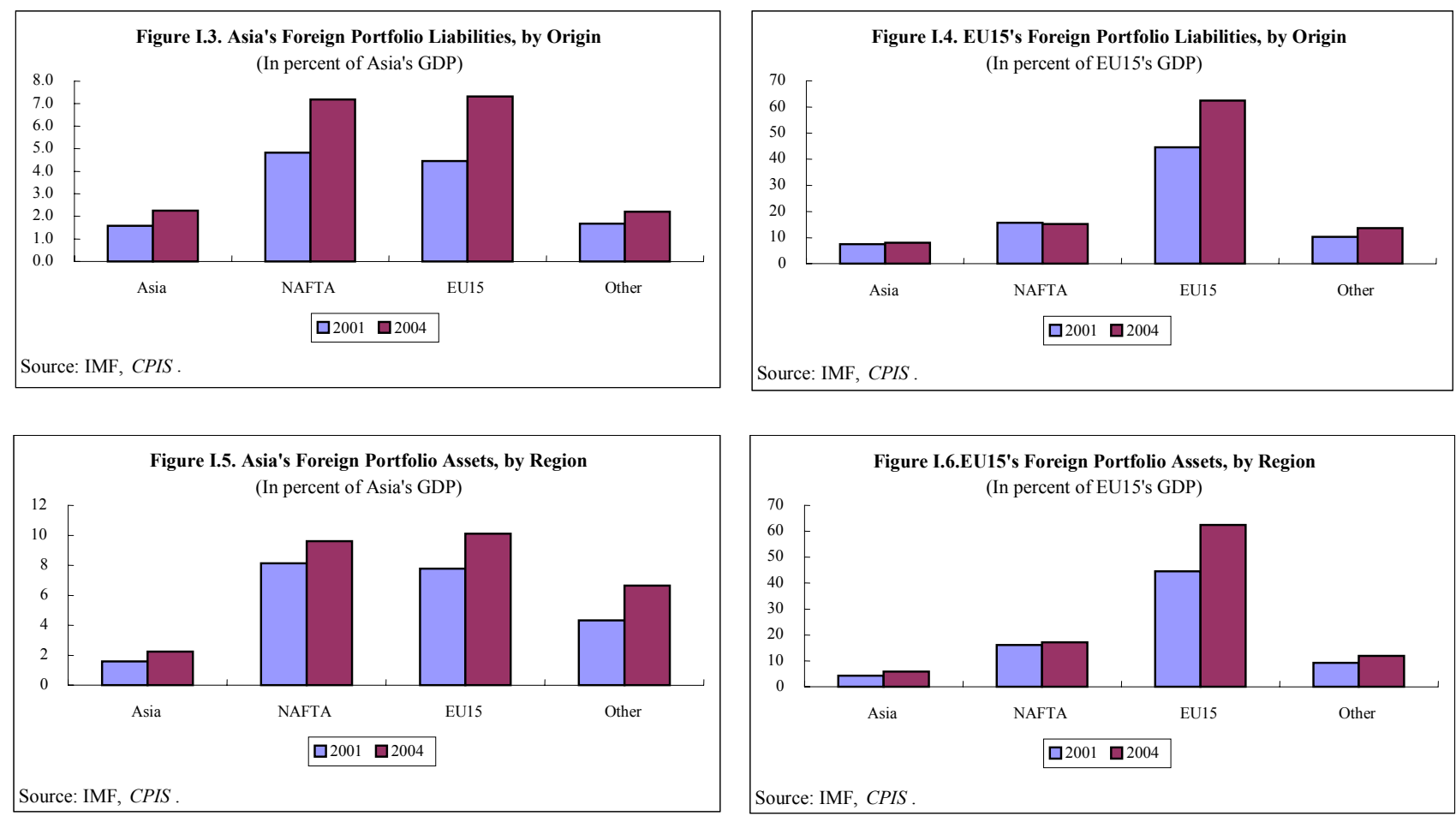

Although growing in absolute terms and as a share of GDP, Asia's intraregional cross-border portfolio investment is relatively small. For example, Asia's portfolio liabilities to other Asian countries amounted to only 21/4 percent of Asia's GDP in 2004, less than one-third the liabilities to either North America or the European Union (EU) - for each region about 71/4 percent of Asia's GDP. ${ }^{5}$ Moreover, liabilities to these two regions rose by a larger amount during 20012004 than intraregional liabilities. A similar pattern holds for Asia's portfolio assets. Asian

\footnotetext{
${ }^{5}$ In the figures, North America or NAFTA is defined as Canada, Mexico, and the United States, while the European Union or EU15 is defined as Austria, Belgium, Denmark, Finland, France, Germany, Greece, Ireland, Italy, Luxemburg, the Netherlands, Portugal, Spain, Sweden, and the United Kingdom.
} 
investments in either North America or the EU-at almost 10 percent of Asia's GDP each in 2004 - were roughly four and a half times that within Asia, although intraregional asset holdings by Asia grew faster than inter-regional holdings during 2001-2004. ${ }^{6}$ By contrast, in the EU, intraregional portfolio liabilities and assets dwarf liabilities and assets to any other region and have also been the main source of growth in cross-border flows for the region (particularly as a share of the region's GDP).

The same basic pattern holds for cross-border bank borrowing and lending, with Asian countries dependent more on inter-regional flows than intraregional flows. ${ }^{7}$ Global cross-border claims by Asian banks roughly doubled during 1999-2005, but claims on Asia grew by a slower rate than claims on either North America or the EU, and through 2005, claims on Asia remained smaller than claims on these other two regions. Similarly, European or North American bank claims on Asia were larger and grew faster than Asian bank claims on Asia. By contrast, cross border bank flows within the EU are primarily intraregional.
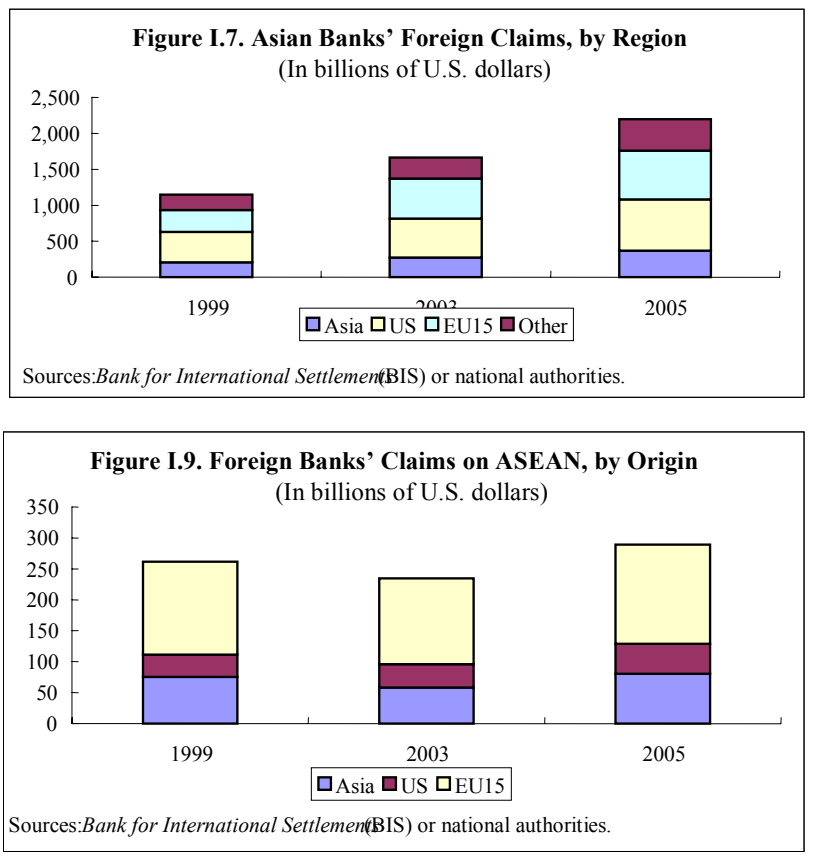
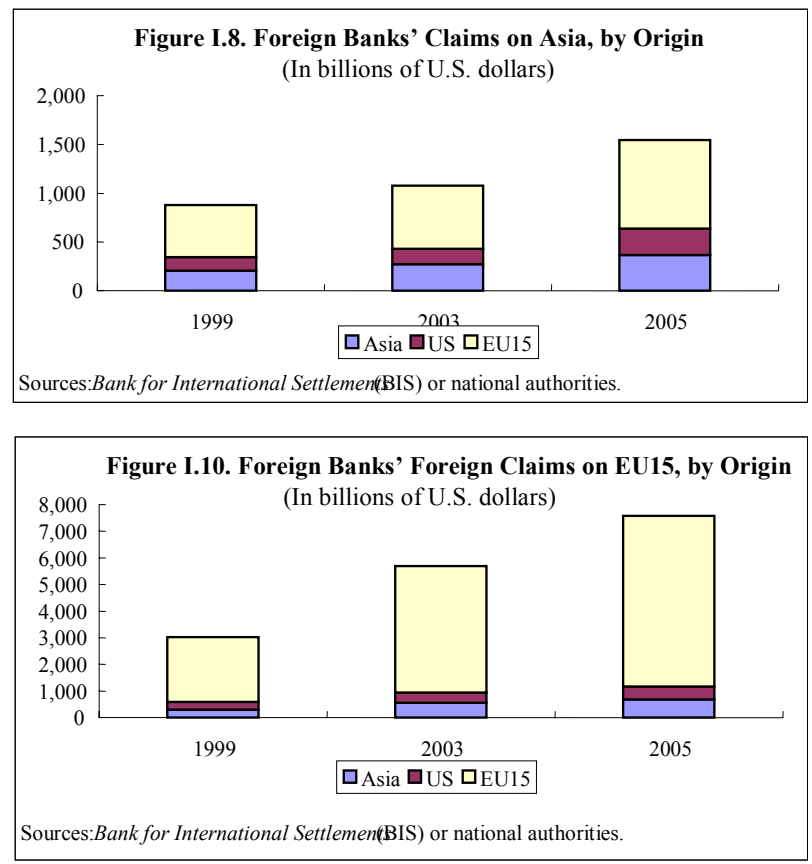

Evidence from price measures of financial integration also suggests that financial remains low, albeit increasing (ADB, 2005). First, although cross-border interest rate and bond yield differentials have narrowed in recent years, these differentials remain substantial, even after

\footnotetext{
${ }^{6}$ In terms of the composition of the assets and liabilities, Asia's intraregional equity and debt assets and liabilities are both small compared with their respective inter-regional counterparts. Similarly, Asian intraregional flows to sub-regions of Asia - for example, the ASEAN countries - are small compared with flows from the European Union or North America.

${ }^{7}$ Cross-border bank flow data are for BIS-reporting banks only. The bilateral data for reporting banks in Asia are published by BIS for only Australia, Japan, and Taiwan Province of China. Data for Hong Kong SAR and Singapore were obtained from the relevant national authorities.
} 
controlling for exchange rate movements. Co-movements in Asian interest rates and bond yields have increased in recent years, but this could also reflect increasing integration with global markets and/or improving fundamentals (such as lower inflation rates and differentials and improved sovereign credit ratings). Co-movements in equity market returns, even after controlling for global factors, suggest that stock markets are more integrated than money and bond markets.

Nonetheless, there has been evidence, primarily anecdotal, of increasing integration of some financial services - namely banking and asset management. Cross-border acquisitions in the banking sector have increased, particularly with a number of purchases by Singapore banks in recent years. This trend is consistent with rising intraregional FDI flows in the financial sector. Also, asset managers and hedge funds have been shifting aggressively into the regionespecially to Hong Kong SAR and Singapore - albeit generally from a low base. In other areas, such as insurance, integration has been more limited.

\section{Intraregional Trade and Financial Integration: The Linkages}

This section touches upon on links between trade and financial integration. It contrasts with the previous two sections, which have highlighted the dissimilarities between intraregional trade and financial integration within Asia. While trade and production integration have proceeded at an apparently rapid pace, financial integration has been relatively sluggish in Asia. Moreover, this picture differs from that in the EU, where financial integration in recent years has been comparatively swift. Overall, the available evidence suggests that trade integration and financial integration are closely linked, although perhaps stronger within the EU and, for Asia, with other regions than intraregionally.

A number of recent research papers suggests that finance follows trade. The results, however, may be influenced by the available data, with creditor data primarily non-Asian. Several channels have been suggested:

- In Rose and Spiegel (2002), a theoretical model is based on the notion that an interruption in international trade ("the penalty") acts as an enforcement mechanism for sovereign debt repayment. With such a penalty, the authors show that in equilibrium the pattern of cross-border borrowing favors the creditor with higher bilateral trade volumes with the debtor. The paper also provides empirical evidence supporting the model, using bilateral bank lending data (for BIS-reporting banks) as the dependent variable from 20 (primarily non-Asian) creditor countries to 149 debtor countries during 1989-1999.

- Forbes and Chinn (2003) find that bilateral bank lending and trade competition are significant determinants of cross-country linkages (although results differ over asset markets and model specifications), but bilateral FDI is not. The paper investigates realfinancial linkages by determining the extent to which bilateral trade flows and FDI, among several factors, can explain financial market returns across countries. Specifically, the authors look at the cross-country linkages between five large economies (France, Germany, Japan, the United Kingdom, and the United States) and 40 developed and emerging 
economies over the period 1986-2000. ${ }^{8}$ Overall, they find that import demand appears to be the most important determinant in their model of cross-country linkages in both stock and bond markets, specifically how shocks to the world's largest economies affect local financial markets (even when controlling for capital account restrictions). The results are most significant for the period 1996-2000, suggesting the linkages are increasing over time. These results also suggest that real factors such as trade intensity may have a strong influence on financial returns, irrespective of the degree of financial integration.

- Eichengreen and Park (2004) analyze why there has been less financial integration in Asia than in Europe. The paper addresses this issue by performing a case study of cross-border bank lending (using the BIS data) in Asia and Europe. The results indicated that different levels of economic development in the two regions (namely, per capita income, even after controlling for economic size in the creditor and debtor countries) are an important factor in explaining differences in bilateral claims. In addition, other differences that are largely predetermined from the point of view of policy (these include typical gravity model variables, such as distance between countries, common language, and sharing a land border) are significant factors. Controlling for these differences, some specifications suggest that Asia is better integrated financially than Europe. Nonetheless, the authors find evidence that Asia is less financially integrated because the region has done less to promote the growth of intraregional trade than has Europe (for example, the establishment of a common market). The results also indicate that capital controlsparticularly, ones that have been maintained for longer periods-and the underdevelopment of financial markets and institutions in potential lending countries have been impediments to regional financial integration. The paper, however, also cautions that quick liberalization could increase financial vulnerability.

\section{By contrast, other papers indicate that trade follows finance:}

- Several papers (for example, Fukao et al., 2003; and Zhang et al., 2005) find that FDI plays an important role in determining trade. As noted in Section II (above), these investments have especially spurred intra-industry trade, particularly vertical intra-industry trade in East Asia and especially China in recent years. Essentially, cross-border investment flows have followed differences in comparative advantages and factor endowments between countries and led to the increased integration, through supply chains and production networks.

- Ronci (2004) suggests that external financing helps determine trade, particularly during crises. The paper shows that disruptions to external trade financing (short-term credit for trade, based on OECD data) explains the fall in trade flows during crisis episodes, after controlling for other factors that may affect trade volumes (such as domestic and external demand, exchange rates, and relative prices). However, the effect is fairly small, except when there is a banking crisis, which could also affect domestic trade financing.

\footnotetext{
${ }^{8}$ Included in this group are Australia, China, Hong Kong SAR, India, Indonesia, the Republic of Korea, Malaysia, New Zealand, Philippines, Singapore, and Thailand.
} 
On this basis, we attempt to establish a link between trade and financial integration for a set of Asian economies. Using annual data on economy-to-economy trade flows from the IMF's Direction of Trade Statistics and portfolio assets (equity and debt securities) from the IMF's Coordinated Portfolio Investment Survey (CPIS), we seek to determine whether these data are positively correlated and, if so, what might be the causal association. To some extent, one might expect the level of bilateral trade flows and financial assets to be strongly correlated, if countries conduct trade in each other's currency. ${ }^{9}$ However, this is not always the case for intraAsian trade, which for some economies is conducted in a third (internationalized) currency. We note the CPIS data are limited to 2001-2004 and do not cover portfolio investments from China, India, and Taiwan Province of China. ${ }^{10}$ In addition, by definition, it excludes FDI and bank lending - important sources of regional financing. On this basis, the following observations can be made:

- Generally speaking, intraregional levels of trade flows and portfolio investment are positively correlated in Asia. The correlation is fairly strong in each economy, except Japan and Thailand. For both countries, especially Japan, the addition of data from the EU and United States causes the correlation coefficients to become significantly more positively correlated. This observation also holds among the industrialized economies in Asia, suggesting that inter-regional links appear to be even stronger for Asian countries compared with intraregional links — not surprising given global orientation of the most of the region's major economies.

- To broaden the measure of financial integration to capture regional bank lending, we add $B I S$ - and individually-reported data on gross bank claims to portfolio asset for the largest money center economies in the region-Japan, Hong Kong SAR, and Singapore. Here, our results do not change significantly, suggesting portfolio investment, despite limits to its size, provides a good measure of financial links in the region.

- At the same time, it is unclear whether trade leads finance, or vice-versa. Owing to the lack of time series data, we limit our analysis to a one-period lag-looking at both levels and changes in trade flows and portfolio assets. Here, no clear signs emerge on causality, although levels rather than changes exhibit stronger positive correlation. ${ }^{11}$

\footnotetext{
${ }^{9}$ We initially focus on the stock rather than flow of financial assets, to see whether economies are acquiring financial positions in each other. However, stock data are not adjusted for valuation changes that might cause asset positions to fluctuate.

${ }^{10}$ In addition, there are several gaps in the data for the countries listed above. Specifically, the CPIS has no reported data in 2004 for investment from Australia to Indonesia and the Philippines, and from Indonesia to Hong Kong SAR. In each case, we use the previous year's data.

${ }^{11}$ This result also holds when EU and U.S. data are included.
} 
- Finally, the annual trade flows and financial flows (or changes in financial assets) appear to have significantly lower positive correlation. Still, the average for the region is positive, but less than that when more global data are included.

Table I.6

\begin{tabular}{|c|c|c|c|c|c|c|c|c|c|c|c|}
\hline \multicolumn{12}{|c|}{$\begin{array}{l}\text { Intra-Asia Trade and Finance 1/ } \\
\text { (correlation coefficients) }\end{array}$} \\
\hline & Australia & $\begin{array}{c}\text { Hong } \\
\text { Kong SAR }\end{array}$ & Indonesia & Japan & Korea & Malaysia & $\begin{array}{c}\text { New } \\
\text { Zealand }\end{array}$ & Philippines & Singapore & Thailand & Average \\
\hline $\begin{array}{l}\text { ASIA 2/ } \\
\text { (including bank lending) } 3 /\end{array}$ & 0.691 & $\begin{array}{l}0.419 \\
0.199\end{array}$ & 0.317 & $\begin{array}{l}0.158 \\
0.332\end{array}$ & 0.577 & 0.680 & 0.842 & 0.801 & $\begin{array}{l}0.590 \\
0.553\end{array}$ & 0.264 & 0.534 \\
\hline ASIA+EU+USA 3/ & 0.798 & 0.813 & 0.463 & 0.931 & 0.807 & 0.742 & 0.675 & 0.777 & 0.676 & 0.576 & 0.726 \\
\hline (including bank lending) 3/ & $\ldots$ & 0.735 & $\ldots$ & 0.953 & $\cdots$ & $\ldots$ & $\ldots$ & $\ldots$ & 0.630 & $\ldots$ & $\ldots$ \\
\hline ASIA (-1) (trade leads finance) & 0.679 & 0.410 & 0.284 & 0.121 & 0.551 & 0.640 & 0.834 & 0.816 & 0.499 & 0.277 & 0.511 \\
\hline ASIA $(+1)$ (trade lags) & 0.661 & 0.408 & 0.322 & 0.156 & 0.598 & 0.766 & 0.756 & 0.805 & 0.498 & 0.263 & 0.523 \\
\hline Trade (level) to $\Delta$ finance & 0.747 & 0.267 & 0.162 & 0.099 & 0.180 & 0.476 & 0.595 & -0.078 & 0.680 & -0.013 & 0.312 \\
\hline Trade (level) $(-1)$ to $\Delta$ finance & 0.737 & 0.224 & 0.136 & 0.045 & 0.143 & 0.434 & 0.583 & -0.077 & 0.617 & -0.014 & 0.283 \\
\hline Trade (level) to $\Delta$ finance $4 /$ & 0.451 & 0.246 & 0.477 & 0.537 & 0.640 & 0.255 & 0.542 & 0.231 & 0.362 & 0.161 & 0.390 \\
\hline Trade (level) (-1) to $\Delta$ finance $4 /$ & 0.444 & 0.232 & 0.483 & 0.517 & 0.622 & 0.247 & 0.540 & 0.240 & 0.323 & 0.172 & 0.382 \\
\hline \multicolumn{12}{|c|}{$\begin{array}{l}\text { 1/ Based on annual trade and portfolio (equity and debt securities) flows for the period 2001-2004. } \\
\text { 2/ Defined here as Australia, Hong Kong SAR, Indonesia, Japan, Korea, Malaysia, New Zealand, Philippines, Singapore, and Thailand (portfolio data not available for } \\
\text { China, India, and Taiwan Province of China). } \\
\text { 3/ Correlation coefficients based on total trade and portfolio investments from and gross external bank claims of reporting economies. } \\
\text { 4/ Includes the EU and United States. }\end{array}$} \\
\hline
\end{tabular}

\section{E. Concluding Remarks}

This paper reviews the degree's of trade and financial integration in Asia and their possible association. Generally speaking, interregional links appear to be stronger for Asian countries than intraregional links, suggesting that regional policymakers need to further strengthen economic ties to garner the full benefits of increased globalization and regional integration. To this end, both trade and financial integration are proceeding in the region in a multilateral and bilateral context. World Trade Organization (WTO) commitments weigh heavily on both goods and services (including financial services), and regional and bilateral trade agreementsexisting and prospective-hold some promise of delivering further gains. At the regional level, financial integration is being further enhanced by initiatives aimed at harmonizing financial regulations, developing financial infrastructure, and deepening financial markets, as well as promoting a degree of monetary cooperation - most notably through the Asian Bond Market Initiatives and Chiang Mai Initiative.

Still, in East and South Asia, both trade and financial integration face a number challenges. On the trade side, the proliferation of preferential trade agreements runs, in principle, the risk of being economically inferior to nondiscriminatory trade liberalization on a most-favored-nation basis and slowing any movement toward a larger Asian common market. So far, little evidence of trade diversion has emerged in the region, although the risk remains that regional trade agreements could become a substitute for multilateral trade liberalization. On financial integration, challenges also loom large, including potentially the limited complementarity of the region's economies, excess reliance on bank financing, and protecting their local systems political interest. 


\section{References}

Abraham, Filip, and Jan Van Hove, 2005, "The Rise of China: Prospects for Regional Trade Policy," Review of World Economics 2005, Volume 141, No. 3 (Kiel: Kiel Institute of World Economics), pp. 486-509.

Asian Development Bank (ADB), 2005, Asia Bond Monitor 2005 (November).

CEIC Economic Database, CEIC Data Company Ltd. (Hong Kong).

Bank for International Settlements, BIS Quarterly Review, various editions.

Eichengreen, Barry and Yung Chul Park, 2004, "Why Has There Been Less Financial Integration in Asia Than in Europe?" Monetary Authority of Singapore Staff Paper No. 28 (Berkeley: Monetary Authority of Singapore).

Forbes, Kristin, and Menzie Chinn, 2003, “A Decomposition of Global Linkages in Financial Markets Over Time, mimeo.

Fukao, Kyoji, Hikari Ishido, and Keiko Ito, 2003, "Vertical Intra-Industry Trade and Foreign Direct Investment in East Asia" Journal of Japanese and International Economies 17, pp. 468-506.

International Monetary Fund, 2005a, Asia and Pacific Regional Outlook (September).

_, $2005 \mathrm{~b}$, "Rewards and Challenges from Asia's Financial Integration," Background Paper for the First High-Level Seminar on Asian Financial Integration, Singapore (September).

—_, 2006, Asia and Pacific Regional Economic Outlook (May).

— Coordinated Portfolio Investment Survey, various editions.

- Direction of Trade Statistics, various editions.

- International Financial Statistics, various editions.

Mercereau, Benôit, 2005, "Financial Integration in Asia: The Risk-Sharing Gains for Australia and Other Countries," Australia: Selected Issues, IMF Country Report 05/330 (Washington: International Monetary Fund), pp. 26-40.

Monetary Authority of Singapore, 2005, "Trade and Investment in the ASEAN Region: From Flying Geese to Cross-Border Production Networks," Macroeconomic Review, Vol. IV, Issue 1 (April), pp 86-100.

Ng, Francis, and Alexander Yeats, 2003, "Major Trade Trends in East Asia: What Are Their 
Implications for Regional Cooperation and Growth?” World Bank Policy Research Paper 3084 (June) (Washington: The World Bank).

Ronci, Marcio, 2004, "Trade Finance and Trade Flows: Panel Data Evidence from 10 Crises,” IMF Working Paper 04/225 (Washington: International Monetary Fund).

Rose, Andrew K. and Mark Spiegel, 2002, “A Gravity Model of International Lending: Trade, Default and Credit,” CEPR Discussion Paper No. 3539 (London: Centre for Economic Policy Research). Available on the Web at: http://www.cepr.org/pubs/dps/DP3539.asp

Tumbarello, Patrizia, 2006, “Are Free Trade Agreements in Asia Building or Stumbling Blocs?” (unpublished; Washington: International Monetary Fund).

Zhang, Jianhong, Arjen van Witteloostuijin, and Chaohong Zhou, 2005, "Chinese Bilateral Intra-Industry Trade: A Panel Data Study for 50 Countries in the 1992-2001 Period," Review of World Economics 2005, Volume 141, No. 3 (Kiel: Kiel Institute of World Economics), pp. 510-40. 


\section{ROLE OF InSTITUTIONS AND MARKETS TO FOSTER FINANCIAL INTEGRATION AND ECONOMIC STABILITY ${ }^{12}$}

\section{A. Introduction}

What are the market infrastructure and regulatory frameworks needed to reap the benefits - and contain the risks - of financial integration? What are the next steps for institutional reform and development in Asia?

There are well-known benefits from increasing financial integration in Asia. Benefits include greater competition and efficiency of financial institutions, product innovation, lower cost of capital, longer maturity of financing, greater diversification of risks, greater liquidity in traded securities, increased transparency, more sophisticated risk management, and improved trading and settlement practices. Overall, financial integration can help a country develop its financial sector, making resource allocation more efficient and the economy more resilient to shocks. At the same time, financial integration carries risks that must be anticipated and managed. Foremost is the greater volatility of capital flows, which may result in sharp changes in interest and exchange rates that have negative consequences for the real economy. Financial product innovation and increasing liberalization may reduce costs and risks but can also expose investors to new risks. There are also potential risks from increasing cross-border linkages, through abrupt changes in capital flows or contagion. These risks raise important issues regarding the sequencing of liberalization, and balancing the risks and benefits of integration.

In the first seminar held last September, the consensus was that Asian financial integration had lagged intraregional trade integration. Liquid and well-regulated capital markets were viewed as essential for the effective allocation of the region's savings and to strengthen the region's resilience to domestic and external shocks. Future steps to encourage financial integration should include the development of financial market infrastructures, such as clearing and settlement systems and credit-rating agencies, as well as the harmonization of financial regulatory and supervisory standards in line with international norms and best practices. This would set the stage for greater cross-border flows of capital and financial services.

What are the key reforms needed to promote greater financial integration in Asia? Financial services are conditioned by a host of factors - affecting demand and supply — such as cost and availability of funds, transparency, well-developed infrastructures, prudential regulation, and market openness. This paper provides background information on key reforms in these areas that would facilitate greater financial integration in Asia. These reforms are designed to (i) strengthen capital markets so as to increase investor sophistication and improve the investment climate; (ii) build regional infrastructures to facilitate trading; (iii) minimize risks associated with greater integration; (iv) remove impediments to cross-border activities; and (v) harmonize rules and practices across the region, as well as with global norms and best

\footnotetext{
${ }^{12}$ Prepared by Brian Bell, Mali Chivakul, Hemant Shah, Leslie Teo, and Yuji Yokoburi.
} 
practices, to instill confidence (Figure II.1). Obviously, reforms must recognize the diverse state of development of Asian economies and should be adapted and sequenced to countryspecific circumstances. These reforms are also interlinked. For example, steps to build strong market infrastructures among economies to encourage regional trading and investment will not be effective if there are regulatory impediments that discourage cross-border activities.

Figure II.1. Key Reforms to Foster Integration

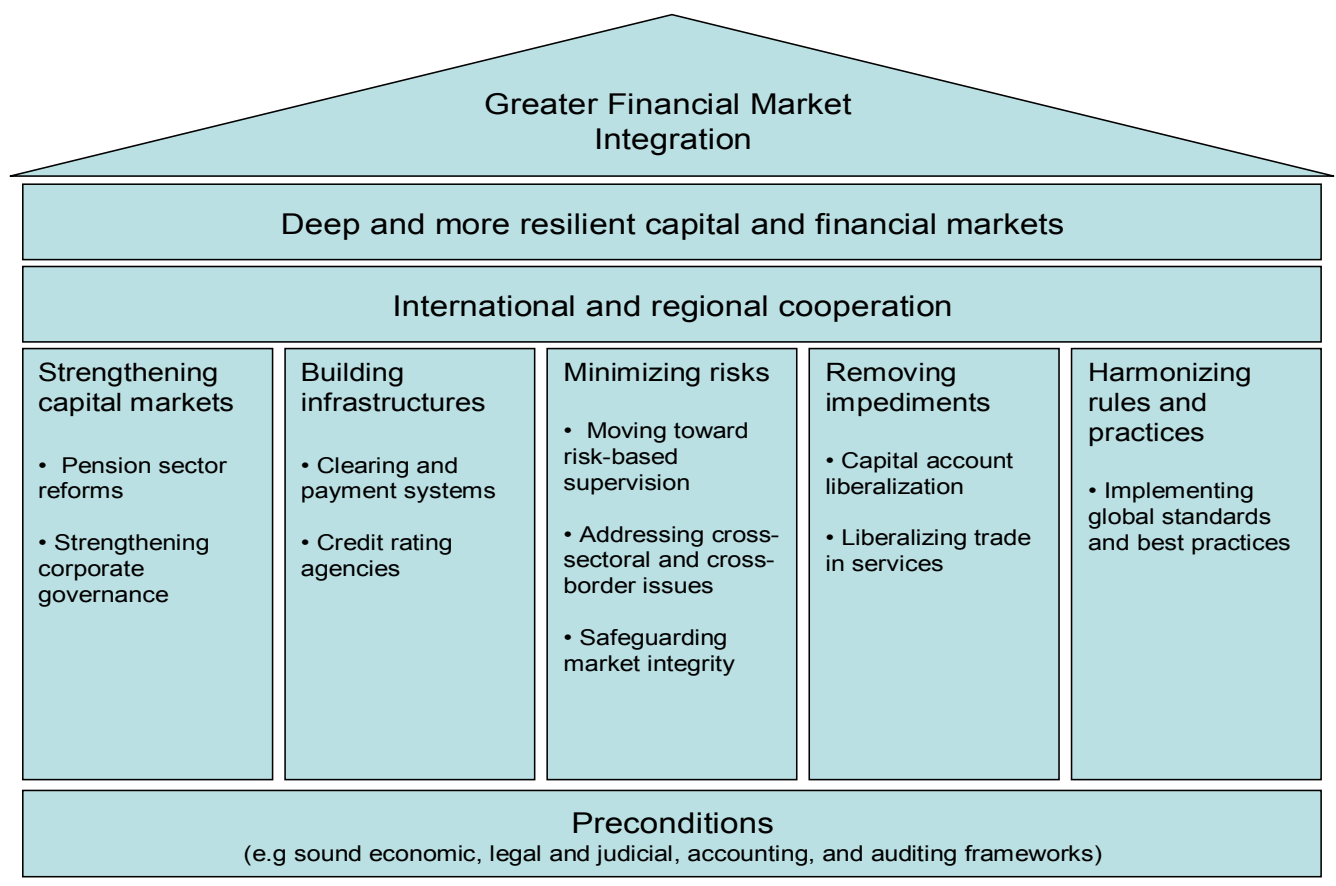

These key areas for reforms are well-recognized and Asian policymakers have already started many initiatives to address challenges in these key areas. These include steps to create regional Asian financial markets, such as the Asian Bond Market Initiative, the Asian Bond Fund (ABF), increased links between stock exchanges, and the Association of Southeast Asian Nations (ASEAN) Finance Roadmap; to collaborate in adopting global standards and best practices; and to establish regional mechanisms for crisis management and prevention.

Nevertheless, further reforms could foster well-functioning financial systems and lay the groundwork for greater integration. In Section B, we discuss reforms to strengthen capital markets while Section $\mathrm{C}$ touches on needed improvements to domestic and regional market infrastructures. As financial integration carries risks that must be anticipated and managed, Section D focuses on the appropriate steps to deal with such risks. Section E identifies some remaining barriers to cross-border flows and transactions and considers issues pertaining to further liberalization. Section $F$ then discusses the task ahead in harmonizing rules and practices, including supervisory and regulatory frameworks. Section $\mathrm{G}$ explores regional and international mechanisms to foster integration and manage attendant risks as key areas for reforms - both domestic and regional — can benefit from regional and international cooperation. Section H concludes. 


\section{B. Strengthening Capital Markets}

The integration of Asian financial markets with the global financial system is well advanced. By contrast, intraregional financial investments are surprisingly low (Appendix II.1). Many Asian countries have therefore recycled their savings elsewhere. At the same time, domestic firms continue to depend excessively on bank intermediation. The reasons for stronger financial linkages are wellknown - better risk sharing, more efficient allocation of capital, more productive investments, and ultimately more resilient economies. Asian policymakers have recognized the importance of strengthening capital markets, and many initiatives have been launched, at the national and regional level's to deepen domestic markets and establish panAsian markets. What more can be done? Here we focus on three areas for further reforms: (i) developing institutional investors, especially pension funds; (ii) strengthening corporate governance; and (iii) improving the transparency and consistency of financial statements.

\section{Developing institutional investors}

Reforms aimed at strengthening the investor base by increasing the role of institutional investors - asset managers, insurance companies, and pension funds - can have a profound impact on the development of regional capital markets. Apart from macroeconomic stability which fosters long-term financial savings, the impact of institutional investors in broadening and deepening capital markets could be strengthened by the appropriate tax treatment for longterm saving products, the transparency of such financial products, the ability of foreign institutions to enter domestic markets, and a level playing field vis-à-vis banks in competition for household savings. Rules on permissible products and investment guidelines - especially for equity or foreign securities - may also need to evolve over time and thereby facilitate the development of regional markets and new financial instruments.

Pension reforms are a key measure. Historically, pension funds in Asia have been statesponsored and defined benefit. These pension funds have generally invested in domestic instruments issued by governments. Reforms could include liberalization to allow for a move away from state-sponsored plans, greater choice between defined benefit or contribution schemes, and changes in regulations to allow pension funds to better manage their risks.

Table II.1. Pension Fund Portfolio Allocation

(as a percent of total)

\begin{tabular}{lrrccc}
\hline & Cash/deposits & Debt securities & Equities & Other & o/w foreign \\
\hline Australia & 7.7 & 15.9 & 52.7 & 23.7 & 22.4 \\
Hong Kong SAR & 20.0 & 24.0 & 56.0 & - & 46.0 \\
Indonesia & 70.9 & 12.8 & 4.1 & 14.1 & - \\
Japan & 2.4 & 33.7 & 21.0 & 42.9 & 17.1 \\
Korea, Rep. of & 7.4 & 90.6 & 0.2 & 1.9 & - \\
Malaysia & 9.0 & 70.4 & 20.0 & 0.6 & - \\
New Zealand & 2.7 & 30.5 & 64.8 & 2.1 & 76.0 \\
Singapore & 2.7 & 96.4 & - & 0.9 & - \\
Thailand & 5.1 & 78.2 & 13.7 & 3.0 & 3.0 \\
United Kingdom & 3.3 & 14.5 & 66.8 & 13.0 & - \\
United States & 3.7 & 23.1 & 59.8 & 13.3 & - \\
\hline Sources: Aus & 3.7 &
\end{tabular}

Sources: Australian Bureau of Statistics, BOJ, IMF, Malaysia EPF, MPFA, New Zealand's Superannuation Fund, OECD, Thailand Government Pension Fund, and IMF staff calculations.

Notes: Coverage is not complete in all countries. Figures are as of 2005 for Australia, Hong Kong SAR, Japan and New Zealand, 2004 for Indonesia, the Republic of Korea, Malaysia, Singapore, and Thailand, and 2001 for the United Kingdom and the United States. 
Many Asian countries are increasingly promoting private pension provision and this trend is to be encouraged. As populations age across the region, publicly provided defined benefit pensions have become increasingly costly. A multi-pillared pension system can help relieve the burden and allow for more flexibility. Encouraging the development of privately funded pensions can also increase the flow of long-term institutional savings and boost the overall development of the financial market. At the same time, greater risk-taking on the part of individuals - especially if defined contribution schemes were to become widespread-would require stronger consumer protection and increased financial literacy.

\section{Strengthening corporate governance}

Strengthened corporate governance is essential for deep and liquid financial markets. As investors are ever more demanding and discriminating, strong corporate governance creates an attractive investment climate. Corporate governance in Asia has generally improved since 2000. However, the prevalence of controlling holdings of companies by families or other corporations continues to place importance on the protection of minority shareholders. Such protection includes facilitating proxy voting, pre-emptive rights for existing shareholders to participate in capital increases, and mandatory disclosure of underlying and interlocking shareholdings. There is also a need for cost effective legal channels for shareholders seeking redress to ensure that rights can be practically enforced. Takeover codes are an important element to ensure a fair market for corporate control and examples such as the Hong Kong, SAR and Singapore Codes on Takeovers and Mergers provide a useful model to follow. The increasing number of countries that have received corporate governance assessments as part of the ROSC program is encouraging and policy recommendations from these assessments should be pursued.

Table II.2. Corporate Governance Ratings, 2000-2004

\begin{tabular}{lccccc}
\hline & 2000 & 2001 & 2002 & 2003 & 2004 \\
\hline China & 3.6 & 3.4 & 3.9 & 4.3 & 4.8 \\
Hong Kong SAR & 7.1 & 6.8 & 7.2 & 7.3 & 6.7 \\
India & 5.6 & 5.4 & 5.9 & 6.6 & 6.2 \\
Indonesia & 2.9 & 3.2 & 2.9 & 3.2 & 4 \\
Korea, Rep. Of & 5.2 & 3.8 & 4.7 & 5.5 & 5.8 \\
Malaysia & 3.2 & 3.7 & 4.7 & 5.5 & 6 \\
Philippines & 2.9 & 3.3 & 3.6 & 3.7 & 5 \\
Singapore & 7.5 & 7.4 & 7.4 & 7.7 & 7.5 \\
Thailand & 2.8 & 3.7 & 3.8 & 4.6 & 5.3 \\
\hline
\end{tabular}

Source: Asian Corporate Governance Association.

Note: Based on an analysis of more than 400 companies. Questions were on all aspects of corporate governance, each rated between 0 and 100 and then averaged for the whole country.

The role of the Board of Directors in protecting shareholder rights is fundamental and more training and guidance for this role is needed. One option is to establish training programs for Directors to provide them with a better appreciation of their role and responsibilities, as in the case for Thailand which has been running a Directors Certification Program since 1999. In addition, the establishment of board committees for listed companies can improve accountability. Many Asian countries require companies to have an audit committee but do not 
similarly require remuneration or nomination committees. Making sure boards have a minimum number of independent directors is also important. Finally, insider trading regulations need to be strengthened and rigorously enforced in a number of countries and related party transactions need to be made more transparent.

Corporate governance standards in the banking sector require special attention, given the dominant role banks play in regional finance. Shortcomings in the governance of banks not only lowers returns to shareholders, but can also destabilize the financial system. Particular attention needs to focus on family-owned banks to ensure that related-party lending between the bank and its owner family (or associated companies) occurs in a manner consistent with sound banking practices, and on state-owned commercial banks to avoid state interference in these banks' commercial activities. These issues are explored extensively in the Asian Roundtable Task Force on Corporate Governance of Banks in Asia and the recommendation to develop independent rating mechanisms for the governance of banks deserves consideration.

\section{Improving transparency}

Increased transparency and accountability through moving to a common financial reporting framework - the International Financial Reporting Standards (IFRS) - is another key reform. This will not only facilitate the access of domestic companies to international capital markets but it will also provide foreign investors more efficient access to domestic markets. Further, a common accounting standards framework can reduce the costs for maintaining multiple accounting frameworks for companies that operate in or obtain financing from different jurisdictions. To ensure the consistent application of IFRS, external audit of financial statements should preferably be based on the International Standards on Auditing. A regional or national supervisory body that ensures the quality and consistency of the auditors' work (similar to the Public Company Accounting Oversight Board created by the Sarbanes-Oxley Act of 2002) could increase public confidence in the transparency and quality of the financial statements.

\section{Building Market Infrastructures}

In addition to more sophisticated investors, stronger corporate governance, and greater transparency, well-developed market infrastructures - domestically and regionally — can help foster regional financial integration. Well-functioning capital markets, especially government bond markets, facilitate financial intermediation and risk management; regional linkages facilitate cross-border capital flows. Again, this is an area where Asian policy-makers have started many initiatives in the last few years. In many Asian countries, market infrastructures have been developed nationally but, apart from a few exceptions, regional systems and linkages are rudimentary. The remaining agenda includes steps to: (i) enhance the depth and liquidity of capital markets, especially bond markets; (ii) establish links between national clearing and payments systems; and (iii) create regional credit rating agencies and benchmarks. 


\section{Enhancing market depth and liquidity}

Further steps to improve transparency, encourage diverse participants, and develop derivative markets could enhance depth and liquidity in capital markets. For instance, bond markets have been developing rapidly since the 1997 crisis, supported by domestic and regional initiatives. Nevertheless, while the primary issuance market works well, there is poor liquidity in most secondary markets. A number of steps could be taken to address this.

- First, measures could be taken to enhance transparency to promote market participation, and hence market liquidity. For example, disclosure of information about the general issuance strategy could help market participants to formulate their investment strategies. Also, trade information in the secondary market should

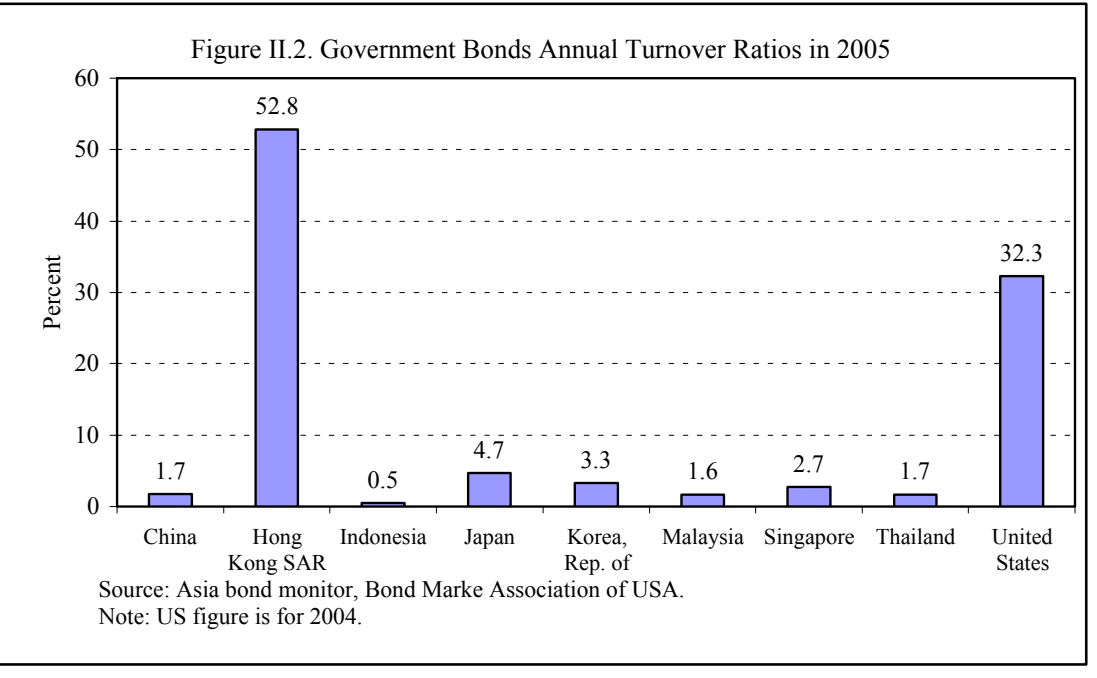
be promptly disclosed to the public, with due attention to ensuring anonymity of market participants. For instance, OTC trades in fixed income securities should be reported on a prompt basis to a central system (such as the BIDS system used in Malaysia). For illiquid assets, it is important that bond pricing agencies exist to provide independent valuations for portfolios. Korea has established bond pricing companies to provide such a service. A related issue is pricing of credit risk. Standards for rating requirements may need to be strengthened to ensure consistency.

- Second, diverse participants could be encouraged to participate. Different market participants with a variety of transaction needs and investment horizons would promote liquidity. On example are the reforms to develop institutional investors discussed earlier.

- Third, related markets and facilities such as futures, swaps, repos, and securities lending enable different investors to construct their investment portfolios and risk management strategies, hence increasing liquidity and trading activities. A recent example has been the development of securities lending through a web-based custodian service (ISCAP) in Malaysia.

- Fourth, changes to prudential regulations or accounting conventions that might hinder trading. Examples include high statutory liquid asset requirements or accounting regulations that require financial institutions to value their portfolios at lower of cost or market value. These requirements may inadvertently discourage secondary trading. 


\section{Linking clearing and settlement systems}

Clearing and settlement processes are well-developed in many Asian markets, so attention could focus on establishing regional linkages. Previous studies show that most markets in Asia have fairly advanced clearing and settlement processes and are increasingly adopting Delivery versus Payment (DVP) systems. In addition, the development of supra-national clearing and settlement systems would improve the liquidity of regional bond markets and help attract more regional investors (Box II.1). Bilateral links between national Central Securities Depositories (CSD) have not taken off in the region but rising levels of cross-border trading will increase the need for efficient and safe infrastructure platforms. There has been much discussion in the past on the possibility of creating an International CSD for Asia (AsiaClear), though thought could also be given to working with existing ICSD's such as Euroclear to develop a cost-efficient global service without needless infrastructure replication. Many countries have used Euroclear for their debt issuance to increase the ease of investment for non-residents. Obviously, steps to develop regional links should be driven by a viable commercial case.

\section{Box II.1. Clearing and Settlement Systems Linkages Between Selected Asian Countries}

Many Asian economies' settlement systems are linked with the international CSDs. This is more to enable international market participants to trade and settle local government bonds than to facilitate local market participants trading and settling international bonds. However, there are currently only very few links within the region and those that do exist are infrequently used.

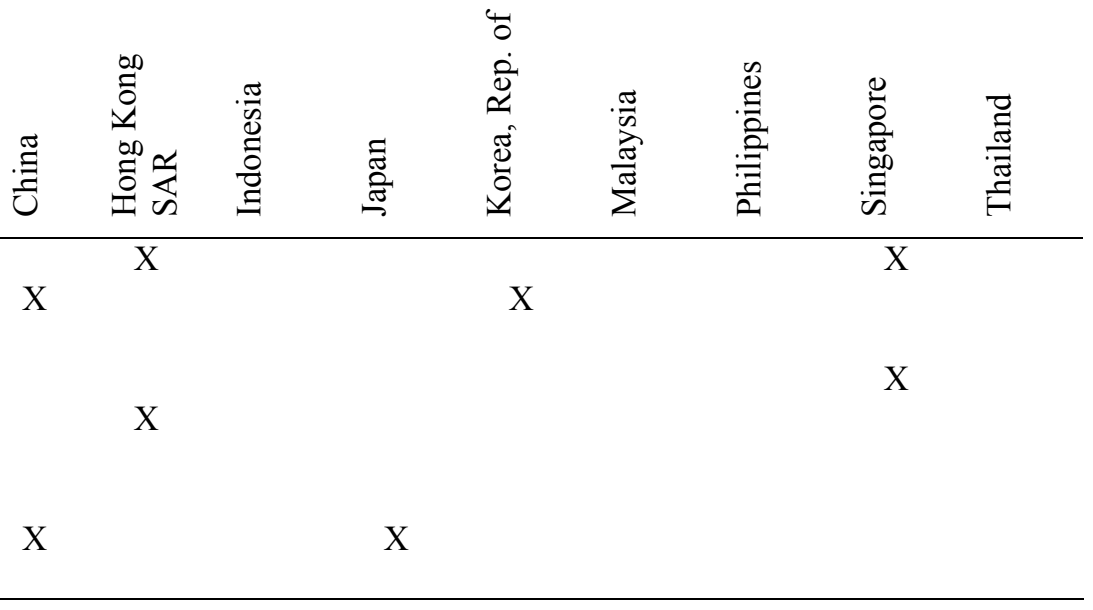

\begin{tabular}{lllll}
\hline China & & $\mathrm{X}$ & $\mathrm{X}$ & $\mathrm{X}$ \\
$\begin{array}{l}\text { Hong Kong, SAR } \\
\text { Indonesia }\end{array}$ & $\mathrm{X}$ & & & $\mathrm{X}$ \\
$\begin{array}{l}\text { Japan } \\
\text { Korea, Rep. of }\end{array}$ & & $\mathrm{X}$ & & \\
$\begin{array}{l}\text { Malaysia } \\
\text { Philippines }\end{array}$ & & & & \\
$\begin{array}{l}\text { Singapore } \\
\text { Thailand }\end{array}$ & $\mathrm{X}$ & & $\mathrm{X}$ & \\
\hline Source ADB & & &
\end{tabular}

Source: ADB

\section{Regional credit rating and benchmarks}

The development of a regional risk rating agency should also be facilitated, as a means of ensuring standardized ratings and a more complete coverage. Most countries in the region have well-developed ratings agencies, many affiliated with the major international agencies (Moody's, S\&P, and Fitch) (Box II.2). The standards being used by these agencies are similar and it should be reasonably straightforward to adopt unified rating standards across the region. The convergence of current national rating agencies into stronger regional rating agencies may 
also be beneficial in terms of economies of scale and standardization. This may lead to greater coverage by rating agencies of small and medium sized companies that have issued securities.

\section{Box II.2. Cooperation among Credit Rating Agencies in Asia}

While there are some 30 domestic credit rating agencies operating in Asia, a survey of international and domestic investors conducted by the Asian Bankers Association (ABA) suggests that they are still in their development stage as regard to (i) timeliness of rating actions; (ii) accuracy and quality of reports and analysis; and (iii) credibility.

In order to address these issues, the Association of Credit Rating Agencies in Asia (ACRAA) was organized in September 2001. Currently, it has 22 credit agencies as members from 12 economies in the region including: Bangladesh, China, India, Indonesia, Japan, the Republic of Korea, Malaysia, Pakistan, the Philippines, and Thailand. Its objective is to exchange information, experiences, and skills among credit rating agencies in Asia to enhance their role in providing reliable market information. It also aims to undertake activities to promote (i) the adoption of best practices and common standards that ensure high quality and comparability of credit ratings; and (ii) the development of capital markets in Asia and cross-border investment throughout the region.

\section{Minimizing Risks}

Greater financial integration brings about risks that have to be anticipated and managed, especially as institutions and individual invest in new markets and instruments. Aside from the potential for currency mismatches and risks arising from country exposures, risks also arise from institutions that are increasingly active in a variety of financial sectors and geographical regions. How should such risks be managed? A strong framework for prudential regulation and supervision is necessary to ensure that risks arising from integration are being assessed and managed well. At a minimum, this involves a move towards risk-based supervision, and changes in prudential regulation and supervisory oversight to address cross-sectoral and crossborder activities.

\section{Moving towards risk-based supervision}

National authorities in Asia have made commendable progress in introducing risk-based supervision, although effective implementation will take time. Supervisors recognize that they have to go beyond a compliance or "checklist" based approach in supervision to one that requires a thorough understanding of an institution's activities and its risks. Most supervisors in Asia have made progress in issuing guidelines and procedures for assessment of different risks and in developing the required databases. However, the capacity to understand risk and effectively supervise institutions will take time and experience to develop. For banking, moving towards risk-based supervision is also key for effective implementation of the Basel II framework.

Risk-based supervision is necessary to effectively manage risks from new investors and more sophisticated financial products. These investors and instruments - such as hedge funds and securitized instruments - have brought much benefit by broadening the investor base and providing more avenues to raise capital as well as to manage risks. At the same time, the 
combination of low risk premiums and untested elements of risk management, especially in an environment where markets are still developing, continue to be concerns. Of course, this is not just a concern in Asia but also for the global financial system. Regulators and supervisors need to be mindful of these risks.

In banking, Basel II provides a more risk-sensitive prudential and supervisory framework even if several issues have to be considered during implementation. Many Asian countries have indicated that they will adopt the Basel II framework (Appendix II). This raises several issues including (i) capacity to supervise banks on a risk-based approach, (ii) home-host information sharing and coordination, and (iii) competitive inequalities and the need to upgrade domestic banks. Cross-border cooperation is essential in implementing Basel II as some supervisors in Asia may implement the advanced approaches later than the home supervisors (or vice versa). In addition, cooperation between home and host supervisors is necessary to ensure different capital requirements do not lead to regulatory arbitrage or unexpected risk migration. For authorities, it is important that meeting self-imposed deadlines for implementation does not take precedence over the quality of the implementation.

\section{Addressing cross-sectoral and cross-border issues}

Consolidated supervision - and close cooperation among sector supervisors - is needed to deal with risks from diversified financial groups. Financial groups are susceptible to contagion as problems can be transmitted within the group through intra-group transactions and reputation effects. In many developing Asian countries, supervisors are still in their early stages of implementing consolidated supervision, both on a domestic and a global basis. Furthermore, as found in many BCP assessments, co-operation among supervisors in the different sectors needs to be improved.

Table II.3. Examples of Local Financial Conglomerates in Selected Asian Countries

\begin{tabular}{|c|c|c|}
\hline Country & Financial conglomerates & Group members/subsidiaries \\
\hline Hong Kong SAR & BOCHK & Credit card \\
\hline \multirow[t]{2}{*}{ India } & State Bank of India & $\begin{array}{l}\text { Securities firm, asset management, credit card, life } \\
\text { insurance }\end{array}$ \\
\hline & ICICI Bank & $\begin{array}{l}\text { Securities firm, asset management, venture capital, life } \\
\text { and general insurance. }\end{array}$ \\
\hline \multirow[t]{2}{*}{ Indonesia } & Bank Mandiri & $\begin{array}{l}\text { Insurance, general investment, securities, leasing, and } \\
\text { finance. }\end{array}$ \\
\hline & $\mathrm{BNI}$ & Securities, insurance, investment, leasing and finance. \\
\hline \multirow[t]{2}{*}{ Japan } & $\begin{array}{l}\text { Mitsubishi UFJ Financial Group } \\
\text { (MUFG) }\end{array}$ & $\begin{array}{l}\text { Securities frim, asset management, consumer credit, } \\
\text { credit card, real estate, venture capital. }\end{array}$ \\
\hline & Mizuho Financial Group (MFG) & $\begin{array}{l}\text { Securites firm, asset management, credit card, venture } \\
\text { capital. }\end{array}$ \\
\hline \multirow[t]{2}{*}{ Korea, Rep. Of } & Kookmin Bank & Asset management, venture capital, life insurance. \\
\hline & Woori Financial Group & Securities firm, asset management. \\
\hline \multirow[t]{2}{*}{ Malaysia } & Maybank Group & $\begin{array}{l}\text { Investment bank, securities firm, asset management, } \\
\text { insurance. }\end{array}$ \\
\hline & Bumiputra-Commerce Holdings & $\begin{array}{l}\text { Securities firm, asset management, venture capital, life } \\
\text { and general insurance. }\end{array}$ \\
\hline \multirow[t]{2}{*}{ Philippines } & Metrobank & Investment bank,credit card, leasing and financing. \\
\hline & Bank of the Philippine Islands (BPI) & $\begin{array}{l}\text { Saving bank, asset management, securities firm, } \\
\text { international fund transfer. }\end{array}$ \\
\hline \multirow[t]{2}{*}{ Singapore } & DBS & Securities firm, asset management. \\
\hline & $\mathrm{OCBC}$ & Asset management, insurance. \\
\hline \multirow[t]{2}{*}{ Thailand } & Bangkok Bank & Securities firm, asset management. \\
\hline & Krung Thai Bank & $\begin{array}{l}\text { Asset management, real estate, life and general } \\
\text { insurance. }\end{array}$ \\
\hline
\end{tabular}


With deeper cross-border linkages, improved cross-border supervision and cooperation is also increasingly important. Both home and host supervisors will need to work together to ensure effective oversight. Efficient cooperation and information sharing requires that each supervisor is equipped with strong risk assessment capability, clear prudential regulations, and ability to take remedial measures. Cooperation between supervisors is especially important when dealing with problems or issues faced by regionally or globally active financial institutions. This would include information sharing, global monitoring of risks, as well as coordinating remedial actions or crisis management, including lender of last resort arrangements. These considerations may become complicated as some institutions become "too-big-to-fail"-in one or many jurisdictions. At a minimum, home and host supervisors need to have in place memorandum of understandings (MOUs) that sets out agreements on these issues so as to underpin effective supervision and crisis management.

Table II.4 Major Financial Groups with Cross-Border Presence in Selected Asian economies 1/

\begin{tabular}{|c|c|c|}
\hline Financial Groups & Presence & Notes 2/ \\
\hline Citigroup & $\begin{array}{l}\text { All } 10 \\
\text { economies }\end{array}$ & $\begin{array}{l}\text { 3rd largest bank in Hong Kong SAR; 7th largest in the Republic of Korea after } \\
\text { an acquisition of a local bank; 5th largest in the Philippines. Also has a stake in } \\
\text { the 6th largest bank in China. }\end{array}$ \\
\hline Standard Chartered & $\begin{array}{l}\text { All } 10 \\
\text { economies }\end{array}$ & $\begin{array}{l}\text { 8th largest bank in the Republic of Korea after an acquisition of a local bank; } \\
\text { 10th largest bank in Thailand; and a controlling stake in the 8th largest bank in } \\
\text { Indonesia. }\end{array}$ \\
\hline HSBC & $\begin{array}{l}\text { All } 10 \\
\text { economies }\end{array}$ & $\begin{array}{l}\text { Largest bank in Hong Kong, SAR. Also has a stake in the } 5 \text { th largest bank in } \\
\text { China. }\end{array}$ \\
\hline DBS & $\begin{array}{l}\text { All } 10 \\
\text { economies }\end{array}$ & $\begin{array}{l}\text { Largest bank in Singapore; } 5 \text { th largest in Hong Kong SAR. Also has a stake in } \\
\text { the 2nd largest bank in Philippines and the 6th largest bank in Thailand. }\end{array}$ \\
\hline UOB & $\begin{array}{l}\text { All } 10 \\
\text { economies }\end{array}$ & $\begin{array}{l}\text { 2nd largest bank in Singapore; } 9 \text { th largest bank in Thailand. Also has a } \\
\text { controlling stake in the 12th largest bank in Indonesia. }\end{array}$ \\
\hline $\mathrm{OCBC}$ & 6 economies & $\begin{array}{l}\text { 3rd largest in Singapore; } 11 \text { th largest bank in Indonesia. Its insurance subsidiary } \\
\text { is the largest in Singapore and Malaysia. }\end{array}$ \\
\hline MUFG & $\begin{array}{l}\text { All } 10 \\
\text { economies }\end{array}$ & Largest bank in Japan. \\
\hline MFG & $\begin{array}{l}\text { All } 10 \\
\text { economies }\end{array}$ & 2nd largest bank in Japan. \\
\hline Sumitomo-Mitsui & 9 economies & 3rd largest bank in Japan. \\
\hline
\end{tabular}

\section{E. Removing Impediments}

The removal of capital and exchange controls could increase cross-border flows and competition. This would enable investors and firms to tap regional markets to find the lowest cost of funding and highest risk-adjusted return. Capital controls in Asia have been gradually liberalized and, in general, no longer stand in the way of cross-border investments in many countries. However, rules in some countries still inhibit cross-border flows while in others, limits on the level of ownership and associated rights still remain (Appendix III). In many countries, the existing prudential requirements biases investment toward domestic assets. 


\section{Further capital account liberalization}

While capital accounts in many Asian countries have been gradually liberalized, further steps could be taken to relax restrictions on cross-border investments while maintaining appropriate prudential safeguards. Asian countries have made significant progress in opening capital accounts in the past decade and regulations limiting residents from investing or raising funds abroad have been incrementally relaxed. However, there are wide differences across the region. For instance, Australia, Japan, Hong Kong, SAR, New Zealand, and Singapore, have the most open markets with limited restrictions on cross-border investment and by and large these relate to non-economic considerations. Korea and Thailand have also increasingly opened their markets to cross-border investment, especially in the aftermath of the Asian crisis; Malaysia has also relaxed all the emergency measures taken to control cross border investments. In other Asian countries, however, various restrictions remain, particularly on resident investments abroad and on the ability of foreign investors to buy in local stock markets. For instance, in China, portfolio inflows are controlled, and only Qualified Foreign Institutional Investors are allowed to invest in A-shares and stock exchange-traded debt securities in domestic markets and in India, inflows by foreign investors are limited. However, in both countries, restrictions on overseas investments by large institutions including pension funds are being slowly relaxed. Obviously, further liberalization has to be sequenced appropriately and conditioned on a wellfunctioning and well-regulated domestic financial system.

\section{Liberalization of financial services and prudential regulation}

There may be a need for countries in the region to prepare for further liberalization of the financial services sector, especially in terms of commercial presence. Based on the General Agreement on Trade in Services (GATS) commitments in 1997, Asian countries made the least commitments to opening up their core banking services and the second lowest commitments after Latin America to open direct insurance services. ${ }^{13}$ Currently, most Asian countries have market access rules for commercial presence that go beyond their commitments in the GATS. However, in many cases, controls and limits remain on ownership share, voting rights, licenses, and branch networks.

Further liberalizing the financial services sector would be beneficial. This applies only to the WTO process, but also to unilateral liberalization or bilateral agreements. Within the WTO process, the WTO Ministerial Declaration in Hong Kong SAR shows a commitment to intensify and expedite the negotiations on trade in services in all modes (Box II.3). Outside the WTO, liberalization of financial services through regional agreements such as ASEAN has not been effective, while a few Asian countries such as Singapore have chosen to open up their financial services sector through bilateral trade agreements.

Another reform is to reexamine prudential limits on pension funds' and life insurers' investments. Most Asian countries have placed quantitative limits on contractual savers'

\footnotetext{
${ }^{13}$ Hoekman and Mattoo (2002).
} 


\section{Box II.3. Liberalization of Financial Services under the Doha Round Negotiations}

The first round of multilateral negotiations on financial services in the context of the GATS was concluded in December 1997, and came into effect in March 1999. Under the Doha Round Negotiations, started in 2001, WTO members agreed on an agenda for comprehensive multilateral trade negotiations that incorporated trade in services.

Asian countries generally agree that liberalization has a long-term benefit but have also called for prudent supervision to protect consumers and manage associated risks. Liberalization must take into account the level of developments of financial markets and the capacity of related institutions. In the latest request, a group of developed countries and a few emerging market countries (including the United States, the European Union, Australia, Canada, Japan, the Republic of Korea, and Hong Kong SAR) have proposed the removal of discrimination between domestic and foreign suppliers regarding application of laws and regulations (national treatment). They are also keen on higher level of commitments on commercial presence, and believe that technological advance calls for a move towards more commitments for cross-border trade especially for some sub-sectors such as financial information and advisory services, reinsurance and retrocession, MAT insurance and services auxiliary to provision of insurance. Their request directly targets many emerging market countries in Asia including China, India, and all ASEAN countries.

investments as opposed to "prudent man" rules. ${ }^{14}$ There is no pressing reason to change this approach if regulations avoid minimum investment limits and allow adequate diversification. However, in many Asian countries, fund assets are invested entirely domestically, and predominantly in government bonds. Thus, even domestic asset diversification has been limited as a result of regulation. As assets under management increase over time as a result of both demographic change and greater coverage, these limits may become more difficult to maintain. In many instances, regulatory limits can interact with a lack of supply of high-quality domestic assets to produce very distorted portfolio holdings. In addition, savers will benefit if portfolios are more optimal in terms of asset and country allocation. Of course, the relaxation of quantitative limits needs to be conditioned on ensuring robust risk management practices within the fund management and under the appropriate regulatory and supervisory framework.

\section{F. Harmonizing Rules and Practices}

An unfinished agenda is to address differences in laws, regulations, and tax treatments that still prevent investors - from both within and outside Asia - from building pan-regional portfolios. This is a difficult and painstaking task, requiring close collaboration among countries and assistance from relevant international institutions and agencies, but it has the potential to produce large payoffs. Where global standards and best practices exist, there are strong benefits from harmonization that is consistent with those standards and practices. Harmonization is particularly crucial in the regulatory and supervisory frameworks for insurance, pension, and securities markets (all crucial for capital market development) as well as banks. Together with efforts to address weaknesses in market integrity, implementation of global standards and best practices is a necessary step to mitigate risks arising from more financial integration; it also serves to instill investor confidence. At the same time, more equal treatment of taxation across the region could facilitate cross-border trading.

\footnotetext{
${ }^{14}$ Instead of quantitative limits, trustees may invest in a security if it is one that would be bought by a prudent man of discretion and intelligence, who is seeking a reasonable income and preservation of capital.
} 


\section{Strengthening implementation of global standards and best practices}

Within regulatory and supervisory frameworks, nonbank financial institutions and capital markets deserve emphasis. These are key if institutional investors-insurance companies and pension funds - and capital markets are to become more integrated. ${ }^{15}$ Key challenges are:

- In insurance, the establishment of full-fledged regulatory and supervisory regimes. There is a need to strengthen solvency regulation and supervision, which then has to be complemented with sound corporate governance and effective risk management.

- The improved regulation and supervision of provident and pension funds. This would benefit members and increase the transparency of these institutions. While banks and insurance companies in Asia generally operate subject to a regulatory framework, there has, with a few exceptions, been an absence of a regulatory body for provident and pension funds. As these funds are often monopoly providers, there tends to be little competition for customers, giving the importance of robust regulation an added significance. The Mandatory Provident Fund Schemes Authority (MPFA) of Hong Kong provides an example of one possible approach, while India has a bill before parliament to approve the creation of a new regulatory body for pension funds.

- Effective supervision of the contractual savings sector - asset managers, life insurers and pension funds. As the sector is liberalized, supervision will be increasingly important. Proper risk management is crucial to the stability of these institutions if asset requirements are liberalized and investment is based on prudent man rules. At the same time, the move towards investment-linked products and defined contribution private pension schemes shifts investment risks to individuals and should therefore be underpinned by effective disclosure regimes and professional market conduct.

- For capital markets, strengthening the supervisor's independence, powers to enforce the rules, and capacity to conduct adequate surveillance. Independence and enforcement are not unique to Asia; these are the main challenges faced by capital market regulators globally. In addition, securities supervisors in Asia need to improve information sharing with other sector supervisors both within the country and abroad.

In addition, weaknesses in the prudential and supervisory framework for banking still need to be addressed. In general, weaker areas include those relating to prudential regulation and requirements, on- and off-site supervision, and provisions for information sharing between supervisors. Further, the BCP assessments suggest that developing Asia lags behind in the principles that are deemed most crucial to adopting Basel II. These include capital adequacy, loan evaluation and loan loss provisioning, risk management systems, consolidated supervision, accounting standards and remedial measures.

\footnotetext{
${ }^{15}$ This section is based on available data from formal standards and codes assessments (see Appendix II.4 for details) as well as other work done by the IMF and World Bank in Asian countries.
} 
Many parts of Asia are considered to be vulnerable to money laundering and terrorist financing activities due to weak AML/CFT regimes and the widespread use of the informal sector to move funds. There are potential reputation risks to individual countries if their frameworks are not improved, such as the curtailment of correspondent banking relationships. The priorities are to implement the key financial sector preventative measures, conduct supervisory oversight of compliance, and undergo assessment of frameworks.

Consideration could be given to reviewing taxes on capital market transactions and the possible benefits of more harmonization across the region. Such taxes may come in the form of transaction taxes and stamp duties; taxes on dividends and capital gains; and withholding tax. Transaction taxes tend to introduce inefficiencies and distortions; taxes on dividends and capital gains could carry an element of double taxation, and withholding taxes can introduce disparate treatment of different taxpayers. The differences in tax regimes across the region, and differences in treatment of residents versus non-residents hinder the development of regional capital markets as they prevent free movement of capital across the region. These problems are fairly universal, and typically dealt with bilateral tax treaties (as with the G-7 countries) that try to balance the revenue and capital market development considerations. A more pro-active regional approach to identifying tax-related problems, and policies toward a more harmonized approach to capital markets taxation would be advantageous.

\section{Regional efforts at harmonization}

Regional efforts at harmonization will be most useful if they are based on globally accepted practices. There is an on-going discussion whether Asia needs its own standard which is different from global standards. It would seem wise to emphasize convergence with globally accepted standards and best practices. For one, this would facilitate easier global integration. In addition, it would also minimize efforts required to create regional standards and best practices.

However, there is scope for flexibility when aligning domestic rules and regulations with global standards. Given the substantial diversity in size and degree of maturity in Asian financial systems, some countries in the region may not be ready to embrace immediate harmonization with global standards and best practices in a given field, but may be able to take concrete steps toward an identified common objective. The more flexible model of cooperation, therefore, seems best suited to the region.

The example of "open coordination" within the EU process for financial coordination may be useful for Asia. Financial cooperation in Europe was based on an "open coordination" model that uses emulation for the spread of best practice and relies on trust and self-control, rather than on legally binding commitments. Under this model, countries work together voluntarily to define common objectives, set regional guidelines combined with specific timetables for meeting objectives, establish qualitative and quantitative benchmarks against best practice, and translate regional guidelines into national policies by adopting specific policies tailored to national circumstances (Box II.4). Of course, harmonization in Europe occurred in the context of greater political and monetary integration, and with possibly lesser differences among member's financial sectors. 


\section{Box II.4. EU's Experience with the Financial Services Action Plan}

The EU commission initiated the 5-year Financial Services Action Plan in May 1999 to create a single market for financial services in the EU. Underlying the plan was the recognition that financial services were increasingly becoming an international market and that any European rule would have to be compatible with those used globally.

The distinctive feature of the plan was that the rules were to be tight and restrictive enough to ensure legal certainty and confidence, but also loose and malleable enough to allow institutions to act and adjust on an international level. It comprised 42 measures to harmonize the member states' rules on securities, banking, insurance, mortgages, pensions, and all other forms of financial transactions.

By its 2004 deadline, 39 of 42 measures were adopted. Among the 21 directives contained in the action plan, the average timeframe for adoption by the European parliament and council was just short of 22 months, which was a significant success for a program of this scale. The plan has been successful not only in harmonizing rules for the financial sector but also in fostering an atmosphere of cooperation between the European institutions and market participants.

For Asia, the main lesson is that harmonization can take place in a de-centralized manner. One way to begin is by conducting diagnostic assessments in each country against global standards and best practices to identify existing gaps. This could be followed by agreement on regional guidelines for practices and rules with which countries could gradually align themselves. The other option for Asia is to adopt a more centralized approach: however, such an approach would require strong political will and consensus.

Some promising advances have already been made through bilateral arrangements or subcommittees and working groups of international and regional fora. For instance, the EMEAP WG on Payments and Settlement Systems has compiled payment and settlement systems assessments in member countries. The OECD/World Bank Corporate Governance Roundtable in Asia continues to provide an avenue to promote a regional framework based on global best practice.

\section{G. Improving International and Regional Cooperation}

Asian countries have made commendable achievements in post-crisis initiatives in financial cooperation including enhanced information exchange and policy dialogue, bilateral reserve sharing, and regional capital market development (Appendix V). Promising efforts involve the ASEAN+3 Economic Review and Policy Dialogue Process and information gathering through the ADB Asia Regional Information Center (ARIC), EMEAP, as well as Chiang Mai Initiative and Asian Bond Fund Initiative. Further, ASEAN+3 countries have recently announced their possible move toward "multilateralization" of the current bilateral swap arrangement under the Chiang Mai Initiative by pooling their reserves, to address its inherent shortcomings of funding uncertainty and inefficiency.

Further areas for cooperation could include the following: 
- Work to establish regional infrastructures such as clearing and payment systems, credit rating agencies, and benchmarks. This would complement ongoing initiatives such as the ASEAN Financial Roadmap and work in EMEAP.

- Efforts to harmonize rules and practices across the region and with global standards and best practices. In this regard, FSAPs and ROSCs could be useful instruments to benchmark Asian countries against best practices and identify priorities for reform. Further, as in the case of Central America, the Euro area, and the Nordic region, the IMF, together with the World Bank where appropriate, has worked with the respective regions to address crossborder regional issues in financial sectors (Appendix VI).

- Cooperation among supervisors at the regional level to complement bilateral relationships. Aside from bilateral meetings and agreements, it may be useful for regulators and supervisors to discuss developments in a regional forum. This may be necessary to identify cross-cutting issues such as concentration risks, large exposures, or risky activities that may not be evident to any one supervisor. This is not unlike the role played by the Financial Stability Forum (FSF) on a more global level.

- Coordination in crisis management. As institutions become active in a number of jurisdictions, crisis management becomes more complicated. Without touching on more intensive, and politically sensitive issues such as solvency support, much could still be done at the technical level to coordinate crisis management and contingency plans. This could involve protocols to share information and resolve practical issues such as public communication, and payments and settlements.

\section{H. Concluding Remarks}

Steps to further develop domestic and regional markets, improve oversight, and strengthen mechanisms for financial sector cooperation and coordination would foster a more integrated Asian financial system. While well known, reforms in these areas require difficult and painstaking work, and will take time to implement and become effective. However, they have the potential to produce large payoffs. The objective of these reforms is to foster healthy institutions and markets that are able to assess and manage risks well. Asian countries will then be able to reap the benefits from more integrated and globalized financial systems while minimizing risks. 


\section{References}

Asian Development Bank, 2004, Monetary and Financial Integration in East Asia, Palgrave MacMillan, New York.

— , 2005, "Bond Market Settlement and Emerging Linkages in Selected ASEAN+3 Countries," Manila.

__ 2004-2005, Asia Bond Monitor, various issues, Manila.

Bank for International Settlements (BIS), 2006 "Developing Corporate Bond Markets in Asia” BIS Papers No. 26 (Basel).

Dalla, Ismail, 2003, Harmonization of Bond Market Rules and Regulations in Selected APEC Economies, (Manila: Asian Development Bank).

Eichengreen, Barry, 2001, "Hanging Together? On Monetary and Financial Cooperation in Asia" (unpublished; [city]: [institution].

European Commission, 2005, "FSAP Evaluation Part I: Process and Implementation."

Fabella, Raul, and Srinivasa Madhur, 2003, Bond Market Development in East Asia: Issues and Challenges, (Manila: Asian Development Bank).

Harwood, Alison, Robert E. Litan, and Michael Pomerleano, 1999, "Financial Markets and Development," Brookings Institution, Washington.

Hoekman, Bernard, and Aaditya Mattoo, 2002, "Financial Services and the GATS," paper presented at a conference on "Further Liberalization of Global Financial Services Markets?” Institute for International Economics, Washington.

International Monetary Fund, 2004, "IMF Staff Note on Basel II," available on the Web at www.imf.org/external/np/mfd/2004/eng/042304.htm.

—_, 2006, "Financial Services Collective Request” (unpublished; Washington).

Plummer, Michael G., 2005, “The ASEAN Economic Community and the European Experience" (unpublished; [city]: [institution]. 


\title{
APPENDIX II.1. KEY FinANCIAL MARKET INDICATORS
}

\author{
Size of Financial Markets (Amount Outstanding) in 2004
}

\begin{tabular}{lcccc}
\hline & Government securities & Corporate bonds 1/ & $\begin{array}{c}\text { Stock market } \\
\text { capitalization }\end{array}$ & Bank credit \\
\hline Australia & 13.8 & 27.1 & 111.5 & 185.4 \\
China & 18 & 10.6 & 33.4 & 154.4 \\
Hong Kong SAR & 5 & 35.8 & 547.7 & 148.9 \\
India & 29.9 & 3.3 & 56.8 & 60.2 \\
Indonesia & 15.2 & 2.4 & 24.5 & 42.6 \\
Japan & 117.2 & 41.7 & 76.9 & 146.9 \\
Korea, Rep. of & 23.7 & 49.3 & 74.7 & 104.2 \\
Malaysia & 36.1 & 38.8 & 140.8 & 113.9 \\
New Zealand & 19.9 & 27.8 & 41.1 & 245.5 \\
Philippines & 21.8 & 0.2 & 37.5 & 49.8 \\
Singapore & 27.6 & 18.6 & 211.4 & 70.1 \\
Thailand & 18.5 & 18.3 & 67.1 & 84.9 \\
United States & 42.5 & 128.8 & 138.4 & 89 \\
\hline
\end{tabular}

Source: IMF, World Federation of Exchanges; Dealogic Bondware; national authorities; BIS

$1 /$ Domestic and international bonds and notes in domestic currency issued by residents and non-residents.

Inter- and Intra-regional portfolio investments in 2003

\begin{tabular}{lrrrrrr}
\hline & \multicolumn{5}{c}{ Investment from } \\
& NAFTA & EU15 & East Asia & $\begin{array}{c}\text { Rest of the } \\
\text { world }\end{array}$ & Total \\
\hline Investment to & & & & & \\
NAFTA & 545 & 1,776 & 747 & 1,620 & 4,688 \\
EU15 & 1,614 & 6,058 & 804 & 1,455 & 9,931 \\
East Asia & 476 & 415 & $\mathbf{1 1 0}$ & 165 & 1,166 \\
Rest of the world & 823 & 1,292 & 566 & 492 & 3,173 \\
Total & 3,458 & 9,541 & 2,227 & 3,732 & 18,958 \\
\hline Source: Asia Bond Monitor & & & & &
\end{tabular}


AUM of Institutional Investors in Asia, End of 2004 (in percent of GDP)

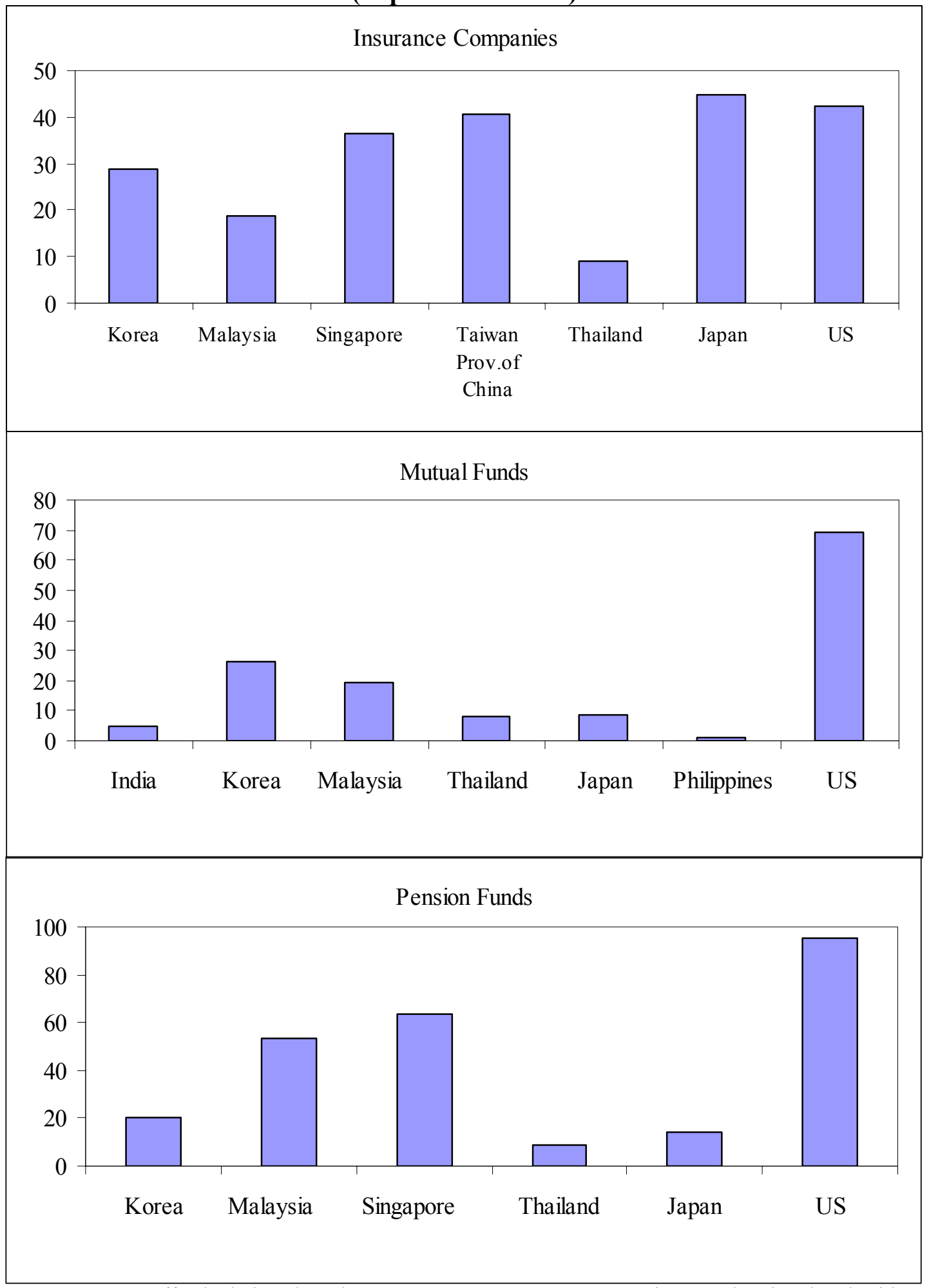

Sources: IMF staff calculations based on IFS, Investment Company Institute, and national authorities. 


\section{ApPendix II.2. Regulations on Cross-Border PortFolio InVESTMEnts in SELECTED ASIAN COUNTRIES}

\begin{tabular}{|c|c|c|c|c|c|}
\hline & \multicolumn{3}{|c|}{ Capital Inflow } & \multicolumn{2}{|c|}{ Capital Outflow } \\
\hline & Money market & Bond market & Equity market & Residents & Nonresidents \\
\hline Australia & Not subject to controls. & Not subject to controls. & $\begin{array}{l}\text { Direct investments by } \\
\text { nonresidents of a particular }\end{array}$ & Not subject to controls. & $\begin{array}{l}\text { No restrictions on } \\
\text { repatriation of capital or }\end{array}$ \\
\hline China & $\begin{array}{l}\text { Non-residents are not } \\
\text { allowed to purchase. }\end{array}$ & $\begin{array}{l}\text { Qualified Foreign } \\
\text { Institutional Investors } \\
\text { (QFIls) are allowed to } \\
\text { invest in listed bonds } \\
\text { subject to quotas. }\end{array}$ & $\begin{array}{l}\text { QFIls are allowed to invest in } \\
\text { A-shares subject to quotas. } \\
\text { No single QFII may hold more } \\
\text { than } 10 \text { percent of a listed } \\
\text { company. }\end{array}$ & $\begin{array}{l}\text { Generally, residents are not } \\
\text { allowed to invest abroad. } \\
\text { Authorized banks may purchase } \\
\text { foreign bonds using their own } \\
\text { foreign currency funds. Foreign } \\
\text { listed companies may } \\
\text { repurchase their own shares } \\
\text { listed abroad subject to approval. }\end{array}$ & $\begin{array}{l}\text { Closed-end QFIls must } \\
\text { keep investments in China } \\
\text { for three years, other QFIIS } \\
\text { for one year. All } \\
\text { remittances abroad must } \\
\text { be done through the firm's } \\
\text { foreign exchange account } \\
\text { upon approval. }\end{array}$ \\
\hline Hong Kong SAR & Not subject to controls. & Not subject to controls. & $\begin{array}{l}\text { Investments in banks above } \\
\text { certain limits require } \\
\text { regulatory approval. }\end{array}$ & $\begin{array}{l}\text { Generally free with limits for } \\
\text { institutional investors. }\end{array}$ & $\begin{array}{l}\text { No restrictions on } \\
\text { repatriation of capital or } \\
\text { profits. }\end{array}$ \\
\hline Indonesia & $\begin{array}{l}\text { Nonresidents are } \\
\text { allowed to purchase } \\
\text { money market } \\
\text { instruments locally. }\end{array}$ & $\begin{array}{l}\text { Subject to regulatory } \\
\text { approval. Non- } \\
\text { residents may not } \\
\text { purchase more than } 1 \\
\text { percent of an } \\
\text { investment fund. }\end{array}$ & $\begin{array}{l}\text { Foreign investors are allowed } \\
\text { to purchase shares without } \\
\text { limitations except for joint } \\
\text { securities companies that are } \\
\text { finance companies as well. } \\
\text { Non-residents may not } \\
\text { purchase more than } 1 \text { percent } \\
\text { of an investment fund. }\end{array}$ & $\begin{array}{l}\text { Banks' transactions with non- } \\
\text { residents are generally restricted. } \\
\text { Insurance and reinsurance } \\
\text { companies are not allowed to } \\
\text { invest abroad except for private } \\
\text { placements overseas insurance } \\
\text { business. }\end{array}$ & $\begin{array}{l}\text { No restrictions apply on } \\
\text { repatriation of capital ore } \\
\text { profits. All payments must } \\
\text { meet reporting } \\
\text { requirements. }\end{array}$ \\
\hline Japan & Not subject to controls. & Not subject to controls. & $\begin{array}{l}\text { Direct investments by } \\
\text { nonresidents in a limited } \\
\text { number of industries, such as } \\
\text { the arms manufacturer, } \\
\text { require prior notice. }\end{array}$ & $\begin{array}{l}\text { Generally free to invest abroad. } \\
\text { Prior notice required for limited } \\
\text { number of industries, and some } \\
\text { limits apply for some institutional } \\
\text { investors. }\end{array}$ & $\begin{array}{l}\text { No restrictions on } \\
\text { repatriation of capital or } \\
\text { profits. }\end{array}$ \\
\hline Korea, Rep. of & $\begin{array}{l}\text { Open to foreign } \\
\text { investors subject to } \\
\text { registration, with } \\
\text { exemptions given if they } \\
\text { reside or work in Korea } \\
\text { for more than six } \\
\text { months. }\end{array}$ & $\begin{array}{l}\text { Open to foreign } \\
\text { investors subject to } \\
\text { registration, with } \\
\text { exemptions given if } \\
\text { they reside or work in } \\
\text { Korea for more than } \\
\text { six months. }\end{array}$ & $\begin{array}{l}\text { Open to foreign investors } \\
\text { subject to registration, with } \\
\text { exemptions given if they } \\
\text { reside or work in Korea for } \\
\text { more than six months. } \\
\text { Investment in banks by non- } \\
\text { residents exceeding } 10 \\
\text { percent of stocks requires } \\
\text { regulatory approval. }\end{array}$ & $\begin{array}{l}\text { There are prudential regulations } \\
\text { on the assets/liabilities } \\
\text { compositions of foreign } \\
\text { exchange banks. Purchase of } \\
\text { non-marketable bonds are } \\
\text { subject to regulatory declaration. } \\
\text { Regulatory approval is required } \\
\text { for purchases of short-term } \\
\text { securities denominated in Korean } \\
\text { Won. }\end{array}$ & $\begin{array}{l}\text { No restrictions on } \\
\text { repatriation of capital or } \\
\text { profits. All remittances } \\
\text { abroad must be in foreign } \\
\text { currency. }\end{array}$ \\
\hline Malaysia & Not subject to controls. & Not subject to controls. & $\begin{array}{l}\text { Investments in banks by } \\
\text { nonresidents are generally } \\
\text { limited to } 30 \text { percent. }\end{array}$ & $\begin{array}{l}\text { Residents without domestic } \\
\text { credit facilities are allowed to } \\
\text { invest abroad. Certain limits } \\
\text { apply to those with domestic } \\
\text { credit facilities, converting MYR } \\
\text { to foreign currency to invest } \\
\text { abroad. Institutional investors are } \\
\text { subject to limits. Registration } \\
\text { required for securities } \\
\text { investments exceeding RM } \\
50,000 \text {. }\end{array}$ & $\begin{array}{l}\text { No restrictions on } \\
\text { repatriation of capital or } \\
\text { profits, subject to the } \\
\text { provision of information on } \\
\text { amounts exceeding RM } \\
50,000 \text {. }\end{array}$ \\
\hline
\end{tabular}




\section{APPEndix II.2. Regulations On CROSS-BORder PoRTFOlio InVESTMENTS IN SELECTED ASIAN COUNTRIES (CONCLUDED)}

\begin{tabular}{|c|c|c|c|c|c|}
\hline & \multicolumn{3}{|c|}{ Capital Inflow } & \multicolumn{2}{|c|}{ Capital Outflow } \\
\hline & Money market & Bond market & Equity market & Residents & Nonresidents \\
\hline New Zealand & Not subject to controls. & Not subject to controls. & $\begin{array}{l}\text { Direct investments by } \\
\text { nonresidents above certain } \\
\text { amount involving the } \\
\text { acquisition of } 25 \text { percent of } \\
\text { shares are subject to a bona } \\
\text { fide investor test. }\end{array}$ & Not subject to controls. & $\begin{array}{l}\text { No restrictions on } \\
\text { repatriation of capital or } \\
\text { profits. }\end{array}$ \\
\hline Philippines & $\begin{array}{l}\text { Registration is required if the } \\
\text { foreign exchange needed to } \\
\text { service the capital } \\
\text { repatriation of dividends, } \\
\text { profits, and earnings is } \\
\text { sourced from local banks }\end{array}$ & $\begin{array}{l}\text { Registration is required } \\
\text { if the foreign exchange } \\
\text { needed to service the } \\
\text { capital repatriation of } \\
\text { dividends, profits, and } \\
\text { earnings is sourced } \\
\text { from local banks }\end{array}$ & $\begin{array}{l}\text { Registration is required if the } \\
\text { foreign exchange needed to } \\
\text { service the capital } \\
\text { repatriation of dividends, } \\
\text { profits, and earnings is } \\
\text { sourced from local banks }\end{array}$ & $\begin{array}{l}\text { Resident's investments abroad in } \\
\text { excess of USD6 million annually } \\
\text { requires prior regulatory approval } \\
\text { For smaller amount, investors } \\
\text { must submit certain } \\
\text { documentations. }\end{array}$ & $\begin{array}{l}\text { Repatriation of capital } \\
\text { gains, profits, or dividends } \\
\text { is allowed without approval, } \\
\text { as long as proof of } \\
\text { registration for the original } \\
\text { investment is available. } \\
\text { Approval required if the } \\
\text { foreign exchange for the } \\
\text { investment will be } \\
\text { purchased from domestic } \\
\text { banks }\end{array}$ \\
\hline Singapore & Not subject to controls. & Not subject to controls. & $\begin{array}{l}\text { Investments in banks above } \\
\text { certain limits require } \\
\text { regulatory approval. }\end{array}$ & Not subject to controls. & $\begin{array}{l}\text { No restrictions on } \\
\text { repatriation of capital or } \\
\text { profits. SGD proceeds must } \\
\text { be converted to foreign } \\
\text { currency. }\end{array}$ \\
\hline Thailand & $\begin{array}{l}\text { No limitation apply except } \\
\text { for certain short term } \\
\text { instruments issued by local } \\
\text { financial institutions. }\end{array}$ & $\begin{array}{l}\text { No limitation apply } \\
\text { except for certain short } \\
\text { term instruments } \\
\text { issued by local } \\
\text { financial institutions. }\end{array}$ & Subject to various limits & Requires regulatory approval. & $\begin{array}{l}\text { Documentation required for } \\
\text { repatriation. }\end{array}$ \\
\hline Vietnam & $\begin{array}{l}\text { Controls apply to all } \\
\text { transactions in money } \\
\text { market instruments. }\end{array}$ & Free & $\begin{array}{l}\text { Foreign investors are allowed } \\
\text { to holdup to } 30 \text { percent of an } \\
\text { issuer's current shares. }\end{array}$ & $\begin{array}{l}\text { Not allowed to invest in shares } \\
\text { and bonds abroad. }\end{array}$ & $\begin{array}{l}\text { Foreign investors may only } \\
\text { transfer investment capital } \\
\text { abroad a year after a VND } \\
\text { denominated securities } \\
\text { trading account is opened } \\
\text { with a custody agent. }\end{array}$ \\
\hline
\end{tabular}

Source: IMF, Asian Bonds Online. 
APPENDIX II.3. IMPLEMENTING BASEL II: ASIA'S INTENTIONS

\begin{tabular}{|c|c|}
\hline & Authorities' plan \\
\hline Australia & $\begin{array}{l}\text { Scheduled to take effect on January } 1^{\text {st }}, 2008 \text {. The vast majority } \\
\text { of authorized deposit-taking institutions (banks, building } \\
\text { societies, and credit unions) are expected to use the Standardized } \\
\text { Approach. }\end{array}$ \\
\hline China & $\begin{array}{l}\text { Large banks with international operations are supposed to } \\
\text { implement Basel II by } 2010 .\end{array}$ \\
\hline Hong Kong SAR & $\begin{array}{l}\text { Planned to implement the Standardized, the Foundation Internal } \\
\text { Ratings Based (FIRB), and the Basic Approaches, together with } \\
\text { Pillar 2, and 3, in January 2007, and the Advanced Internal } \\
\text { Ratings Based (AIRB) Approach in January } 2008 .\end{array}$ \\
\hline India & $\begin{array}{l}\text { Scheduled to take effect from end-March } 2007 \text { for commercial } \\
\text { banks. Initially, the Standardized Approach for credit risk, and the } \\
\text { Basic Indicator Approach for operational risk will be adopted. }\end{array}$ \\
\hline Indonesia & $\begin{array}{l}\text { Planned to be applied in three to five year time frame, starting } \\
\text { from simplest approach in } 2008 \text { to full application in } 2010 \text {. }\end{array}$ \\
\hline Japan & $\begin{array}{l}\text { Scheduled to implement Standardized and FIRB Approaches by } \\
\text { end-March 2007, and AIRB Approach by end-March } 2008 \text {. }\end{array}$ \\
\hline Malaysia & $\begin{array}{l}\text { Planned to implement Standardized Approach in } 2008 \text { and FIRB } \\
\text { Approach in } 2010 .\end{array}$ \\
\hline New Zealand & $\begin{array}{l}\text { Scheduled to implement Standardized Approach in January } 2008 . \\
\text { Banks wishing to implement the Internal Ratings Based (IRB) } \\
\text { and Advanced Measurement Approaches (AMA) from January } \\
2008 \text { must apply to the Reserve Bank of New Zealand (RBNZ) } \\
\text { for accreditation by July 2006, which will be decided on a case- } \\
\text { by-case basis. The RBNZ has a Terms of Engagement with the } \\
\text { Australian Prudential Regulation Authority to ensure a } \\
\text { coordinated approach to Basel II. }\end{array}$ \\
\hline Pakistan & $\begin{array}{l}\text { Planned to start to implement Standardized Approach in } 2008 \text { and } \\
\text { IRB approach in } 2010 .\end{array}$ \\
\hline Philippines & $\begin{array}{l}\text { Planned to start to implement Standardized Approach in } 2007 \text { and } \\
\text { IRB approach in } 2010 .\end{array}$ \\
\hline Singapore & $\begin{array}{l}\text { Scheduled to implement by end-2007 at latest. All approaches } \\
\text { will be available but local banks are not expected to employ the } \\
\text { most sophisticated techniques. }\end{array}$ \\
\hline Korea, Rep. of & Planned to make all options available by end- 2007 . \\
\hline Taipei, China & $\begin{array}{l}\text { Planned to start to implement Standardized and FIRB Approaches } \\
\text { in January } 2007 \text { and advanced approach (AIRB and AMA) in } \\
2008 \text {. }\end{array}$ \\
\hline Thailand & Planned to implement by end-2008. \\
\hline
\end{tabular}

Source: IMF staff. 


\section{APPENDiX II.4. Regional COMPLIANCE WITH STANDARDS AND CODES}

This appendix reviews the reports on the observance of standards and codes (ROSCs) in the areas related to financial sector in Asia. The information used here is from the assessments done both independently by the IMF/WB team and through the Financial Sector Assessment Programs (FSAPs) between 1999-2005. The peer group for developed ${ }^{16}$ Asia is OECD countries while the peer group for developing Asia is middle-income countries. The analysis here should be read cautiously since some assessment are

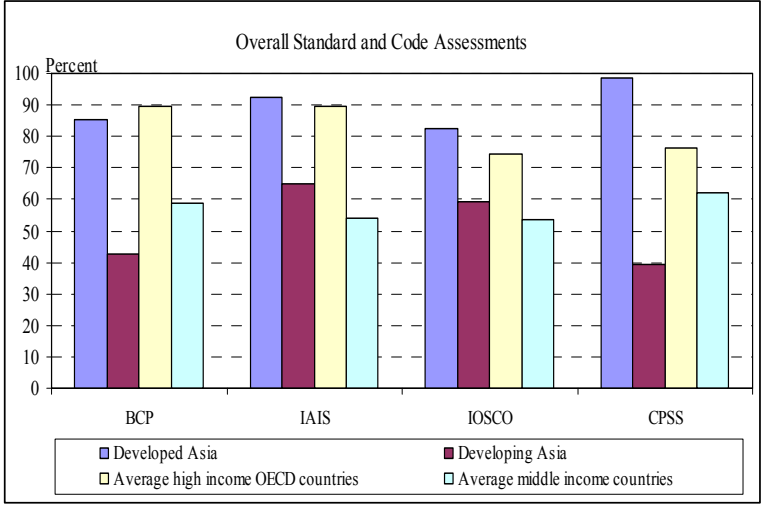
dated and coverage is not complete.

\section{Basel Core Principles (BCPs)}

Developed Asia in general achieved about 85 percent compliance with the BCP, compared to OECD average of 90 percent. BCP assessments identified some weaknesses mainly in the arrangements for sharing information between supervisors, country risk monitoring and control, antimoney laundering practice, and effective on-site and off-site supervision.

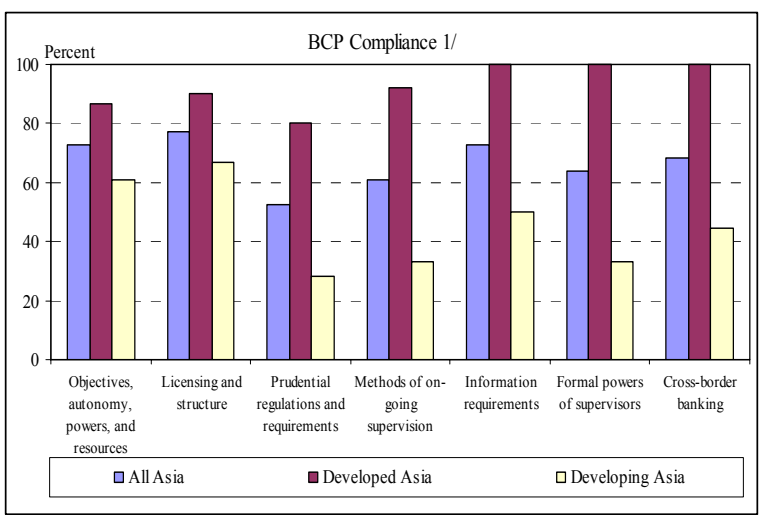

Developing Asia, on the other hand, exhibits lower compliance, compared to the average for middle income countries. Most countries in the sample were materially non-compliant or non-compliant in principles regarding information sharing between supervisors, ownership, prudential regulation and requirements, on-site and off-site supervision, remedial measures, and cross-bordering banking. In addition, no supervisor in the sample practiced consolidated supervision or incorporated country risk control.

\footnotetext{
${ }^{16}$ For the purposes of this appendix, developed Asia includes Hong Kong, SAR, Japan, Korea, New Zealand and Singapore (all countries or a subset of countries, depending on data availability of each standard). Developing Asia includes Bangladesh, India, Indonesia, the Philippines, Sri Lanka and Thailand. All assessments were done in FSAPs except those for Indonesia and Thailand.
} 


\section{International Association of Insurance Supervisors (IAIS) Principles}

On the insurance side, both developed and developing Asian countries in the sample outperform their peers. Main weaknesses for the insurance supervisors around the world lie in corporate governance standards, internal controls and market conduct. In general, Asian systems assessed exhibit the same deficiencies as in other regions, except that all countries in the sample complied with the market conduct principle.

\section{International Organization of Securities Commissions (IOSCO) Principles} Developed Asia in general has implemented or broadly implemented most principles. A few partially implemented principles relate to independence and accountability of the regulator, oversight of self-regulating organization (SROs), and capital and other prudential requirements for market intermediaries.
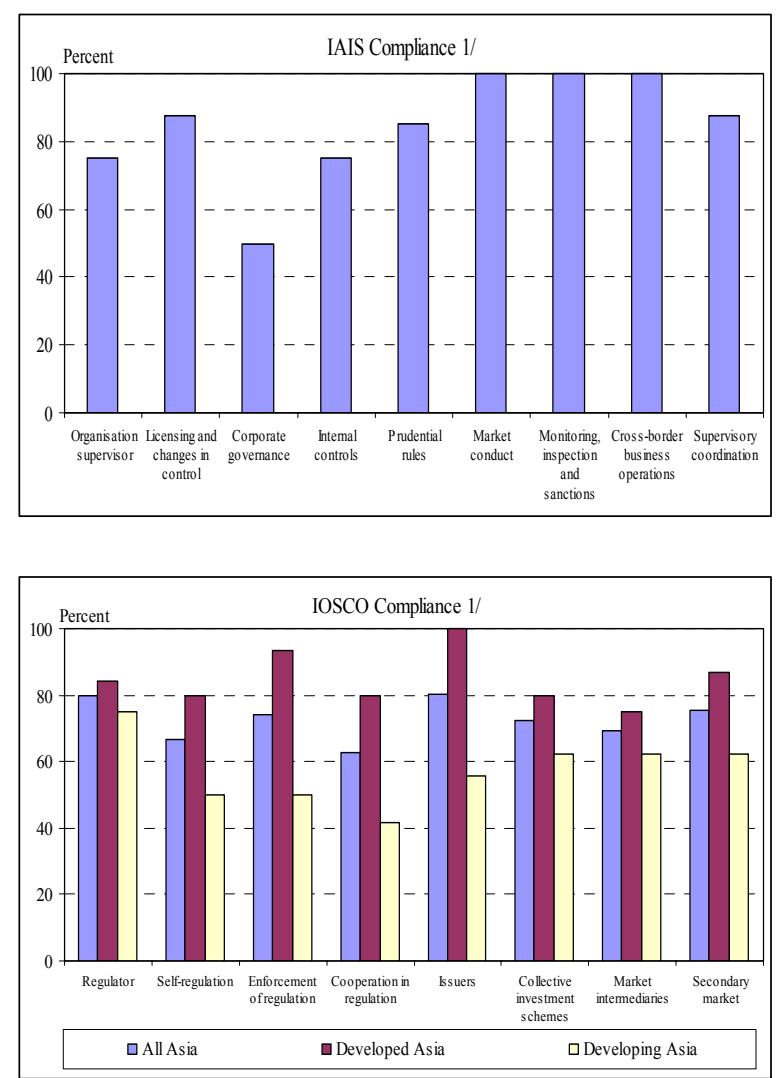

In developing Asia, securities regulators often lack sufficient capacity and consequently do not conduct proper market surveillance. Moreover, no country in the sample had adequate rules and procedures to detect and deter manipulation and other unfair trading practices. Improvement is also needed in the area of information sharing with other supervisors, the use and oversight of SROs, standards for collective investment schemes, and regulation of market intermediaries.

\section{Committee on Payment and Settlement Systems (CPSS)}

Payment systems in developed Asia appears to be of high quality, while compliance in developing Asia is only partial. Most systems, including both large value transfer systems and check clearing systems, in the sample of developing Asian countries do not have sufficiently well-founded legal basis and still lack risk management procedures, prompt final settlement, security and reliability and governance arrangements. In addition, supervisors often have limited capacity to oversee payment systems that the supervisors themselves do not operate. 


\section{Appendix II.5. Asian Regional Policy Forums}

\section{EMEAP (Executives Meeting of East Asia and Pacific Central Banks)}

Established in 1991 as a forum of central banks, aiming at enhanced regional surveillance, exchange of views and information, and financial market development. Currently, there are three Working Groups: WG on Payments and Settlement Systems, WG on Financial Markets, and WG on Banking Supervision.

11 members. Australia, China, Hong Kong, Indonesia, Japan, South Korea, Malaysia, New Zealand, the Philippines, Singapore, and Thailand. The secretariat function is offered by the BOJ.

\section{ASEAN (Association of South East Asian Nations)}

Established in 1967. It has slowly grown from its original five members to current 10 members. The group's economic cooperation covers; trade, investment, industry, services, finance, environmental protection, agriculture, forestry, energy, transportation and communication, intellectual property, small and medium enterprises, and tourism. Since 1999, meetings among representatives of finance ministries and central banks of ASEAN plus China, Japan, South Korea (ASEAN+3) have been held (initially the deputy level, then Ministers and Governors since 2000) to discuss topics such as, financial cooperation, regional surveillance, and human resource developments. A network of bilateral swap arrangement among ASEAN+3 countries is currently in place (Chaing Mai Initiative).

10 members. Brunei, Cambodia, Indonesia, Lao PDR, Malaysia, Myanmar, the Philippines, Singapore, Thailand, and Vietnam (original members in bold). Secretariat is located in Jakarta, Indonesia.

\section{ASEM (The Asia-Europe Meeting)}

Established in 1996. ASEM is an informal process of dialogue and cooperation bringing together ten Asian countries (see below) with the fifteen EU member states and the European Commission. It holds summit level meetings every two year and Ministerial-level meetings in the intervening years (normally once a year). It addresses political, economic and cultural issues, with the objective of strengthening the relationship between the two regions, in a spirit of mutual respect and equal partnership.

26 members. Brunei, China, Indonesia, Japan, South Korea, Malaysia, the Philippines, Singapore, Thailand, Vietnam, the 15 EU member states and the European Commission,.

\section{SEANZA (South East Asia, New Zealand, Australia)}

Established in 1956, one of the oldest and also the largest in terms of membership of the regional policy fora. It is a forum among central banks, to conduct intensive, biennial central bank training courses. The very diversity of this group, however, argues against its practicality as a platform for more intensive central bank cooperation outside the training area. 
20 members. Australia, Bangladesh, China, Hong Kong, India, Iran, Indonesia, Japan, South Korea, Malaysia, Nepal, New Zealand, Pakistan, Papua New Guinea, the Philippines, Singapore, Sri Lanka, and Thailand.

\section{SEACEN (South East Asian Central Banks)}

Established in 1972. Initially a training and research organization for central banks, SEACEN has evolved from an informal grouping in the 1980s to a more substantive forum for discussion of central banking issues (became a legal entity in 1982).

13 members. Brunei, Indonesia, Fiji, South Korea, Malaysia, Mongolia, Myanmar, Nepal, the Philippines, Singapore, Sri Lanka, Taiwan, and Thailand. The SEACEN Centre is located in Kuala Lumpur, Malaysia.

\section{APEC (Asia Pacific Economic Cooperation)}

Established in 1989, originally meetings between only foreign/trade ministers. Finance ministers (central bank governors) began to meet annually since 1994.

21 members. Australia, Brunei, Canada, Chile, China, Hong Kong, Indonesia, Japan, South Korea, Malaysia, Mexico, New Zealand, Papua New Guinea, Peru, the Philippines, Russia, Singapore, Taiwan, Thailand, Vietnam, and the United States. The secretariat is in Singapore.

\section{Six Markets Group (G-6, or G-4 plus 2)}

Established in 1994. Initially, it consisted of only four major Asian financial centers (Australia, Hong Kong, Japan, and Singapore). Since 1997, China and the United States have been invited to attend the meetings as well. The group's objectives include stability of the region's financial and foreign exchange markets. Meetings are attended by Vice Ministers of Finance and Deputy Governors of central banks. 


\section{APPENDIX II.6. FSAP AND ROSC PARTICIPATION BY REGION}

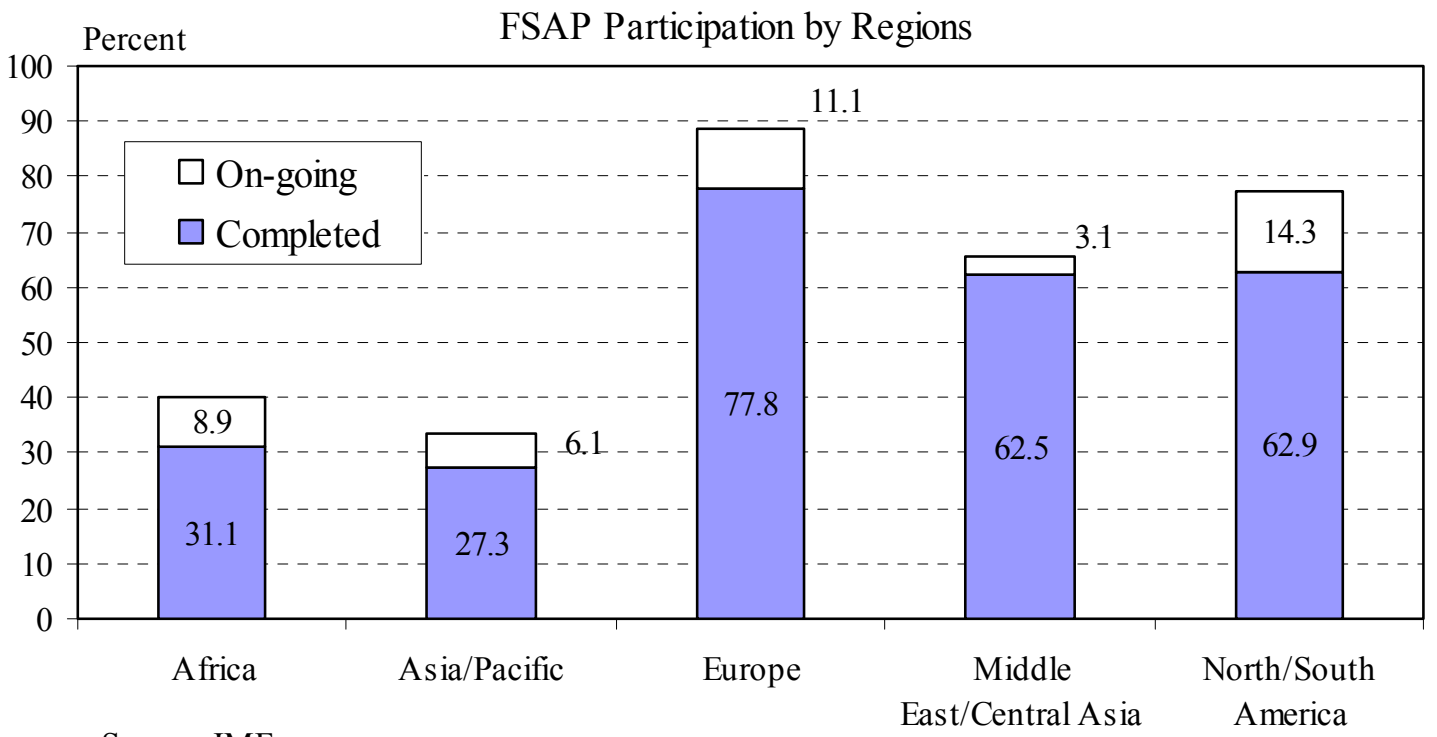

Source: IMF.

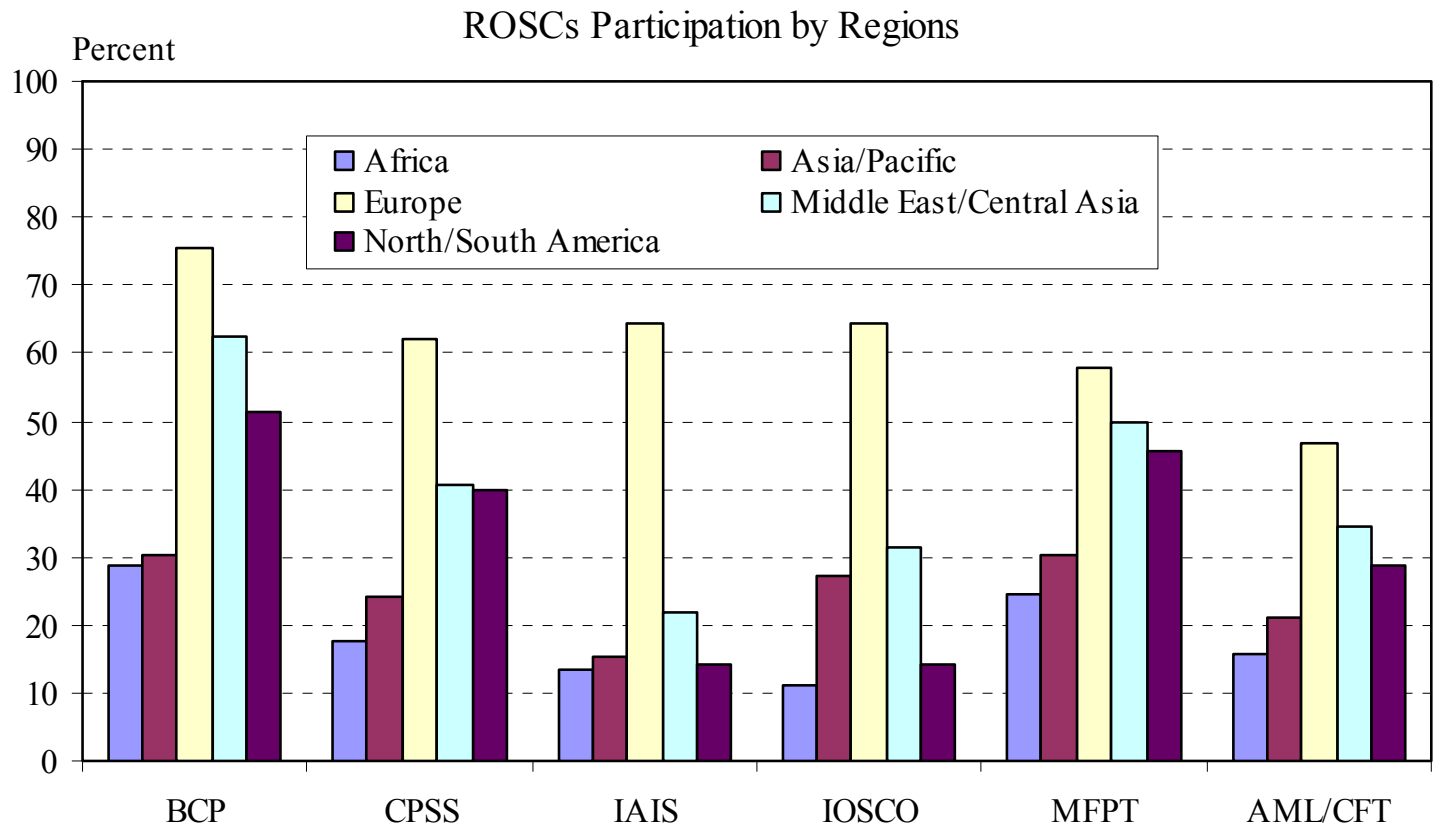

Source: IMF.

Note: Figures include on-going as sessments. 


\section{Regional Integration and Macroeconomic Policies ${ }^{17}$}

\section{A. Introduction}

Economic and financial integration is increasingly affecting national macroeconomic conditions throughout Asia. Adding force to global trends, intraregional trade and capital flows are fostering the synchronization of business cycles and shaping financial developments within the region. A broad pattern is emerging: GDP growth and stock market returns have become more correlated across national borders in recent years, and inflation and interest rates have been converging toward common levels (Figure III.1). Although the evidence so far is only suggestive, the experience of closely interconnected regions around the world underscores that comovements in real and financial variables are likely to become more pronounced as economic linkages grow.

What are the implications of real and financial integration for macroeconomic policies? This paper reviews some of the main issues, both from a short-run and a longer-run perspective. The discussion abstracts from country-specific details and is organized around broad questions. Section B considers options for exchange rate systems in integrated economies. Section $\mathrm{C}$ focuses on the choice of monetary frameworks. Section D touches on some fiscal policy questions. Finally, Section E takes the long-run view and looks at the requirements and implications of monetary unification - a possible outcome once integration locks in a high degree of real and nominal convergence. Section F concludes. A main message of this overview is that policies that hold out the hope of fostering regional integration are also the ones that promise strong economic performances in each country. These policy frameworks need to strike a balance between competing calls for flexibility and predictability in the economic environment as both financial and trade ties deepen-and, in time, will lead to greater convergence and policy harmonization.

\section{B. Exchange Rate Policy}

\section{Flexible, fixed, or a middle ground?}

Regionally integrated economies need to balance trade-offs in the choice of their exchange rate regime vis-à-vis one another. ${ }^{18}$

- On the one hand, predictable external values of national currencies within the region facilitate intraregional trade, simplify economic decisions, and promote cross-border

\footnotetext{
${ }^{17}$ Prepared by Robert Flood, Akito Matsumoto, and Alessandro Zanello.

${ }^{18}$ There is a separate issue of what exchange rate regime an integrated region should have against other currency areas. The attendant trade-offs, explored in the literature on Optimum Currency Areas, on balance favor a flexible exchange rate regime.
} 
holdings of local securities. A system of stable intraregional exchange rates could also ease an eventual transition to a common currency.

- On the other, international capital mobility makes defending intraregional currency pegs difficult, absent close convergence of policies and strong market confidence in the system. In fact, in the "impossible trinity" view, an economy can have only two of the following: an independent monetary policy, a fixed exchange rate, and capital account openness. In the textbook version, a monetary loosening to support GDP growth, for example, would trigger incipient capital outflows that would put downward pressure on the exchange rate peg and lead to an unsustainable drawdown of official reserves. ${ }^{19}$ Something has got to give.

Capital controls do not offer a durable way out of the dilemma. A margin for policy maneuver can perhaps be reconstituted by recognizing that capital account openness is not an all-or-nothing proposition: capital flows can be managed through capital controls. While attractive as a tactical solution, this approach has limitations in practice. Capital controls may provide temporary "breathing space" for the pursuit of domestic policy objectives but their long-term effectiveness is questionable in sophisticated global financial systems. More importantly, barriers to capital mobility entail costs in terms of a less efficient allocation of international savings and the foregone benefits of the diversification provided by unencumbered trade in assets. Recognition of these costs motivates, in fact, the wide-ranging initiatives underway to liberalize financial markets in Asia.

Intraregional exchange rate flexibility is a more promising strategic alternative. Exchange rate systems that do not present one-way bets on the external value of a currency eliminate the rationale for speculative attacks. As a result, they are consistent with steps to encourage intraregional capital flows while safeguarding the ability of policy to pursue domestic objectives. There is a downside, though: excessive exchange rate volatility could hamper trade and complicate investment decisions by heightening uncertainty. A clear commitment to sound macroeconomic policies and the development of forward markets to hedge exposure to exchange rate risk would go a long way toward limiting these undesirable side effects. So would two-way intervention in the foreign exchange market that dampens exchange rate volatility at high frequencies but does not undermine the role of exchange rate movements in the longer-term adjustment to shocks or structural changes. ${ }^{20}$

In sum, while trade considerations may favor greater fixity in exchange rates to lower transaction costs, steps to promote capital mobility point in the other direction. Exchange rate

\footnotetext{
${ }^{19}$ A shift in international capital flows from the fixed income market to the equity market (which benefits from a reduction in interest rates) changes the impact of monetary policy on the direction of capital flows but does not resolve the tension between domestic (e.g., inflation, output) and external (exchange rate) objectives.

${ }^{20}$ In fact, sustained one-sided intervention is powerless to head off the need for adjustment to structural changes, and over time can create imbalances of its own.
} 
systems that allow exchange rates to operate as shock absorbers offer the best hope to resolve this tension. Rare exceptions notwithstanding (Hong Kong SAR, for one), greater exchange rate variability seems unavoidable when the capital account becomes more open. ${ }^{21}$ So, greater flexibility in exchange rate management is a key element in a strategy to foster regional integration: it allows economies to share regional

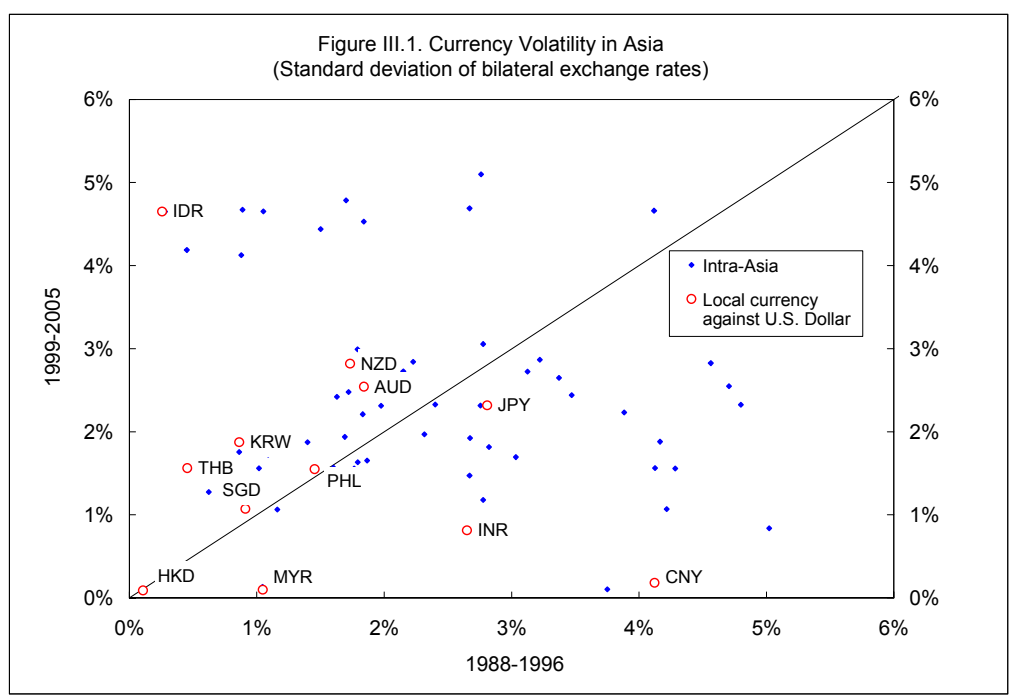
savings and expand trade, without giving up the freedom to pursue domestic objectives at the same time. This is indeed the direction in which emerging Asia has been moving: exchange rate flexibility vis-à-vis both regional and G-3 currencies has been increasing in most cases over time.

\section{Are currency basket pegs an alternative?}

It has been suggested that currency basket pegs could also be an option for regionally integrated economies in emerging Asia. There are two versions to this proposal — one involves each country pegging its currency to a common basket of G-3 currencies, the other would have each country choosing an appropriately weighted basket of currencies including those of intraregional partners. In the first approach, the main focus is to ensure exchange rate stability vis-à-vis the rest of the world and intraregionally. In the second, the main goal is to better capture country-specific features and limit intraregional exchange rate variability to promote trade and investment. Both approaches have been also put forth as possible intermediate regimes on the road to monetary unification.

The rationale for a collective basket peg against G-3 currencies lies in the view that predictable exchange rates against the dollar, the euro, and the yen would facilitate export growth, a pillar of the Asian development model. Common weights in the national currency baskets would also limit intraregional fluctuations in effective exchange rates. In one proposal reminiscent of the (pre-euro) European Monetary System (EMS), a country's exchange rate would be allowed to float within a band around a predetermined nominal value of a basket of currencies. Intervention - perhaps financed by a common pool of reserves-

\footnotetext{
${ }^{21}$ The growing importance of processing trade and global supply chains adds weight to this conclusion. Since firms that are exporting products with little domestic value added are less sensitive to relative price changes than firms exporting goods produced with national inputs, greater exchange rate variability may be needed to offset the impact of lower trade elasticities in the adjustment of external shocks.
} 
would prevent the exchange rate from straying further. Gradual realignments of the central parity would be possible in case of a significant drift in the equilibrium exchange rate. ${ }^{22}$

Critics of this "basket-band-crawl" arrangement question the premise that export-led growth should continue to play a central role in Asia's development. ${ }^{23}$ They argue that productivity growth (which can only indirectly be steered by monetary arrangements), and not the level of nominal wages, holds the key to rising living standards. On this view, exchange rate stability may be less important for growth, going forward. Furthermore, critics note credibility issues related to the adoption of "soft margins" in the target band as well as the political difficulty of re-aligning central parities when the underlying determinants of the equilibrium exchange rate change. ${ }^{24}$ More broadly, the precedent of the EMS - which was supported by panregional political, economic, and financial commitments - is generally seen of limited relevance for emerging Asia where these pre-conditions are still absent. The robustness of a regional exchange rate system depends on shared economic structures, policies, and shocks among participating countries. For this reason, a regional grid of fixed exchange rates would seem at odds with emerging Asia's economic and institutional diversity. A case in point is that trade patterns vary substantially within the region and some countries would be disadvantaged under a common peg. ${ }^{25}$

A variant of the G-3 currency basket proposal focuses on the advantages of a baskettailored to each country - that includes both external and regional currencies. Such a basket arises, for example, if trade weights are used in choosing its composition. By construction, it could not be a common basket. ${ }^{26}$ In principle, a system of country-specific basket pegs would insulate the trade relations of the region from outside disturbances (as the common-basket proposal does) but not fully eliminate intraregional instability in bilateral rates. Whether customized baskets would be superior in stabilizing real exchange rates depends on the relative variability of the external values of the constituent currencies. ${ }^{27} \mathrm{~A}$ further advantage

\footnotetext{
22 This description follows Williamson (1999).

${ }^{23}$ For example, Eichengreen (2001).

24 The success of Singapore in operating a de facto band has been imputed to its exceptionally strong banking and financial system, the authorities' skill in adjusting the band in response to changing domestic and international conditions, pervasive labor market flexibility, strong political backing of the exchange rate system, and the market perception that the implicit band would not be binding in the event of overwhelming pressures.

${ }^{25}$ De Brower (2002) notes that exports of the more developed countries in East Asia are similar to those of the major economies so that it makes little sense for them to trade off competitiveness in third markets against intraregional exchange rate volatility.

${ }^{26}$ For example, China's basket would by necessity exclude the renminbi while the basket of other emerging Asia countries would include it. See Williamson (2005) for details.

${ }^{27}$ Computations using historical volatilities of bilateral rates (Williamson (2005)) show that in most cases a common basket dominates. By contrasts, model-based simulations (in Kamada and Takagawa (2005)) suggest
} 
of country-specific baskets pegs is that they may be better suited to a context of evolving intraregional trade patterns and could represent an interim step toward the adoption of a common basket as real convergence among Asian economies proceeds. ${ }^{28}$

Currency basket pegs tailored to individual members of an integrated region suffer from many of the shortcomings of a common-basket scheme. In addition, there may be heightened difficulties in deciding the appropriate weighting scheme for the component currencies. Should weights be based on import, exports, or total trade? Should they reflect the direction of trade or its currency composition? Should financial flows be considered in the determination of the appropriate weights? Beyond these technical issues, there remains the concern that limited exchange rate flexibility as implied by either sort of basket pegs carries the risk of fundamental inconsistencies between internal or external policy objectives. The "impossibility trinity" casts a shadow on all these proposals.

However implemented, currency pegs would in the end constrain the scope for an independent monetary policy - the more so the more mobile capital is internationally. Preserving the viability of a multilateral grid of pegged exchange rates potentially comes at the expense of domestic price, output, or financial stability. This was what happened during the 1992-93 turmoil in European exchange rate markets that shook the EMS' Exchange Rate Mechanism (ERM) - the system of intraregional currency basket pegs of the time. Insufficient convergence of inflation rates and cyclical divergences between Germany and many other European countries fanned massive speculative attacks on the weakest ERM currencies. In the often-futile attempt to defend existing parities, interest rates increased in the countries under attack, in most cases in conflict with the domestic objective of supporting activity in an environment on increasing economic weakness. ${ }^{29}$ Regional integration may in the end be held back if countries are forced to trade off domestic stability for deeper trade linkages. More broadly, the adoption of currency basket proposals would involve a change from the current systems to which economic agents have already adapted. Barring indisputable evidence of their superiority, a policy change could undermine hard-won credibility. Overall, limiting intraregional flexibility through various forms of basket pegs seems a sensible option only in the very last stages of a transition to monetary unification.

that country specific basket pegs are welfare-enhancing relative to a U.S. dollar peg for emerging Asia, but not relative to current regimes.

${ }^{28}$ This seems to be the spirit of a proposal by Vice-Minister Watanabe at the IMF/MAS September 2005 HighLevel Seminar on Asian Integration. In his view, "basket pegs with converging weights" could play a role in the run-up to an Asian monetary union.

${ }^{29}$ In the event, two currencies were withdrawn from the ERM (the Italian lira and the pound sterling), four realignment took place (of the lira before its suspension from the ERM, the Spanish peseta, the Portuguese escudo, and the Irish pound), and three currency floated (the Finnish markka, the Swedish krona, and the Norwegian krone). Vigorous intervention was required to hold the French franc and the Danish krone within the system, in spite of strong fundamentals in both cases. 


\section{Is there a role for an Asian Currency Unit?}

The view that a currency basket peg could strengthen intraregional integration - and ultimately pave the way for a regional currency - is related to proposals for establishing a basket of regional currencies as a unit of account. ${ }^{30}$ In the Asian context, an Asia Currency Unit (ACU) is in the works. Some observers have noted that the ACU could play the role of the European Currency Unit (ECU) as a stepping stone to monetary unification.

Like the ECU, the ACU would be defined as fixed number of units of the constituent (possibly ASEAN+3) currencies. Thus, the contribution of each individual currency to the value of the ACU would fall or rise with its exchange rate. In principle, official steps such as the denomination of portion of official reserves at participating central banks in ACU or the commitment of participating governments to issue ACU bonds, could make it more attractive for financial and non-financial firms to issue and accept ACU-denominated liabilities and assets. ${ }^{31}$ ACU-bonds could offer the benefit of currency diversification: if one constituent currency lost value against, say, the investor's home currency, the impact would be limited by its weight in the basket. In time, the ACU could become an invoice currency in trade, gaining the status of a medium of exchange as well as that of a store of value and a unit of account.

Be that as it may, history shows that the ECU played a limited part in facilitating the launch of the euro (see for example Eichengreen (2005)):

- Although the ECU was established in 1974 as a unit of account for European Community institutions and in 1979 as the settlement currency for interventions in the EMS, it never acquired a significant role in either capacity. ${ }^{32}$

- The bulk of European transactions continued to be conducted in national currencies until the euro was introduced. "Network externalities" weighed heavily against the widespread usage of the ECU: the benefits of adopting a new money depend on other agents doing

\footnotetext{
${ }^{30}$ Ito (2004), among others, sees the issuance of regional bonds in an Asian composite currency as a step toward exchange rate management based on a common basket peg. Williamson (2005) argues that a basket numéraire of Asian and G3 currencies could be used to fine-tune foreign exchange rate intervention in the region

${ }^{31}$ Underlying contracts would need to specify how private ACU-asset and liabilities would change in value when the composition of the official ACU basket changed. Arbitrage would ensure that the value of the private ACU remain in line with that of the constituent currencies.

${ }^{32}$ Credits under the EMS were extended in national currencies and, although EMS parities were based on an ECU central rate, central banks and markets focused on the derived bilateral rates in national currencies.
} 
the same, but there is no incentive to be the first-mover. With no easy way to resolve this collective action problem, the status quo tends to get locked in. ${ }^{33}$

- With a strong predominance of the U.S. dollar in intra- and extra-European commercial and financial transactions, the need for a new regional currency for invoicing and settlement purposes was weak all along.

- As for the ECU's modest success as a unit of account for bonds, it owed much to currency-plays in the run-up to unification and regulatory barriers to the internationalization of the Deutsche mark. Once these barriers fell, so did the demand for ECU-claims. ${ }^{34}$

Overall, the European experience seems to provide a cautionary tale on the role that the ACU could play in promoting regional integration in Asia. Network externalities and the incumbency of the U.S. dollar as the main invoice currency in intraregional trade are likely to militate strongly against a rapid acceptance of an Asian parallel currency. Further headwinds may arise from the risks to financial stability as banks, firms and households take on ACUdenominated claims. For example, currency mismatches may reappear on banks' books if the growth of ACU-liabilities and assets is not kept in step - the more so, if lack of exchange rate flexibility within the region weakens incentives to hedge open positions. ${ }^{35}$ Tighter supervision and reserve requirements may mitigate these dangers, but there may be a price to pay in terms of forgone intermediation.

The ACU could play a part in the development of regional bond markets, but the benefits may be limited. Dammers and McCauley (2006) underscore the attendant trade-offs. In particular:

- While retail investors may benefit from the pre-packaged diversification provided by basket bonds, institutional investors are less likely to find in the basket weights a close match for the currency distribution of their liabilities or the preferred mix of foreign exchange risk exposure.

- For issuers, the availability of currency swaps to transform liabilities in one currency into liabilities in another may also weaken interest in basket bonds.

\footnotetext{
${ }^{33}$ In the 1990s, only about one percent of intra-Community trade was invoiced in ECU. ECU-denominated claims never amounted to more that 10 percent of the non-dollar foreign currency claims of banks reporting to the BIS. ECU-bonds never accounted more than 20 percent of all non-dollar Eurobonds, and ECU-commercial paper only reached a high of 10 percent of all Euro-commercial paper.

${ }^{34}$ In some observers' view, the euro revived the ECU bond rather than that the euro bond market grew out of the ECU-bond market. See Dammers and McCauley (2006)

${ }^{35}$ Eichengreen (2005).
} 
- The need for underlying contracts to stipulate contingencies in the event of changes in the official composition of the ACU adds a layer of legal complexity that may deter widespread acceptance of ACU-denominated bonds.

- Finally, government issuance of ACU-bonds may take a toll on local bond market liquidity to the extend that it diverts issuance away from national markets or undermines the benefits of large benchmarks. Liquidity may also be adversely affected by the fact that basket bonds tend to attract buy-and-hold investors who want to lock in the diversification benefits they provide.

\section{Monetary Policy}

\section{What monetary framework?}

Unlike a commitment to a fixed exchange rate, freer floating of exchange rates is not an operating strategy for monetary policy. The presumption that greater flexibility in exchange rate systems will support and facilitate regional integration raises the question of what is then an appropriate supporting monetary framework. A popular strategy to accompany (more) flexible exchange rates is a central bank's commitment to the pursuit of price stability.

Price stability, defined qualitatively or operationalized as a target for the inflation rate, has gained broad acceptance as a key goal for monetary policy. A formal inflation-targeting regime requires an institutional commitment to price stability (appropriately defined), mechanisms to ensure accountability of the monetary authority, announced targets for inflation as well as a possible horizon for achieving these targets, and regular reporting to the public and the markets of the rationale for monetary policy decisions. Taken together, these elements define a regime of constrained discretion-balancing the need for flexibility in implementation with the need for a credible commitment to domestic price stability. In other expressions of this commitment, the balance between flexibility and credibility may be made operational in less formal ways.

Country-specific factors will determine the case for adopting inflation targeting, broadly defined. A history of weak central bank independence, reliance on commodity exports, and relative closeness to international trade, all increase the attractiveness of a formal inflationtargeting regime. ${ }^{36}$

- A formal arrangement in which the government sets a clear mandate for the central bank (the inflation objective) but leaves up to the bank the choice of the policy instruments lends credibility to monetary policy makers who might have lacked before operational independence.

\footnotetext{
${ }^{36}$ McCauley (2001) elaborates on these issues.
} 
- Commodity exporting countries are vulnerable to wide swings in the terms of trade, which make it difficult for monetary policy to maintain a fixed exchange rate. Inflation targeting would be for them a more attractive monetary framework. ${ }^{37}$

- Finally, openness to international trade imposes by itself a measure of discipline on the conduct of monetary policy, since any attempt to boost the economy by laxer monetary settings would trigger an exchange rate depreciation and a surge in inflation. On this account, more open economies would have less of an incentive to embrace inflation targeting. Other considerations, however, such as the need to limit the domestic impact of external shocks by adopting a flexible exchange rate regime, strengthen the case for inflation targeting.

In line with these stylized facts, Asia has been moving away from monetary frameworks that favored an exchange rate target toward those that focus on the pursuit of price stability. Several countries in the region are explicit inflation targeters. Most other countries have price stability as a key goal for monetary policy. The few economies that still manage their exchange rates heavily outside of a currency board arrangement seem to be in a transitional stage and steps are being taken to enhance the flexibility of their exchange rate systems. Overall, the transition to inflation-centered monetary frameworks underscores the close connections between deepening trade and financial linkages in the region, on the one hand, and the need for a monetary framework that anchors price and wage expectations, on the other. Flexible exchange rates and monetary decisions geared to the achievement of price stability can - together-contribute strongly to intraregional cohesion.

\section{What is the role of the exchange rate in inflation targeting regimes?}

A commitment to price stability or the adoption of an inflation target does not imply "benign neglect" of the exchange rate. Exchange rates convey information about future movements in prices and output, particularly so in highly open economies. A central bank that, like many in East Asia, tries in practice to minimize deviations of inflation and output from their targets will in general respond to movements in the exchange rates. Its response should of course reflect the anticipated impact of the exchange rate movement on output and prices. It may also be guided by considerations such as the nature of the shock affecting the exchange rate or the desire to limit interest rate volatility. The important point is that inflation targeting does not mean ignoring the exchange rate but rather that the entire operating strategy for monetary policy is not organized around a target level (or range) for that rate.

In fact, a floating exchanger rate takes on a new and useful role in monetary frameworks centered on price stability. For instance, a rapid depreciation may indicate the risk of an inflationary surge, signaling the need for monetary tightening. More generally, sustained

\footnotetext{
${ }^{37}$ The growing importance for Asia of trade in electronic goods, which shares some of the business cycle characteristics of commodities, adds weight to this point.
} 
exchange rate movements can provide early warnings of underlying economic or financial imbalances that warrant a policy response.

\section{Does regional integration facilitate the conduct of monetary policy? And can monetary policy coordination facilitate regional integration?}

As intraregional trade and financial ties grow, the business cycles in individual economies become better synchronized. Country-specific shocks are dissipated throughout the region; and output and inflation tend to co-vary more across national borders. In this setting, the monetary policy requirements of different economies also become similar: the likelihood of contemporaneous shifts in the monetary stance in the same directions across regional economies (e.g., toward tightening) increases. Policy becomes better harmonized — and its intraregional spillovers potentially less disruptive. ${ }^{38}$ For example, with interest rates moving together, volatility in intraregional exchange rates will diminish, limiting the impact of the policy moves on intraregional trade.

Monetary policy coordination may in turn aid regional integration. For example, the choice of a common inflation target would speed up the convergence of national inflation rates to a common level. As nominal and real convergence advances, greater policy coordination becomes critical for an eventual monetary unification.

\section{Fiscal Policy}

\section{How does regional integration affect fiscal decision making?}

A first issue is whether economic cohesion among open and financially interconnected economies constrains the scope for fiscal stabilization at the national level. The standard view holds that intraregional exchange rate flexibility and capital mobility reduce the effectiveness of fiscal policy: other things equal, a fiscal stimulus will put upward pressure on the interest rates and exchange rates, partially crowding out exports and interest-sensitive demand. If monetary policy targets price stability, an induced tightening may further mute the fiscal impact. The point is however a bit academic. There is a growing recognition that the best course for fiscal policy makers is to take on a longer-term orientation and avoid attempts at short-run stabilization — which often run afoul of long decision and implementation lags.

From this perspective, a relevant question is whether regional integration has implications for budgetary financing and broadly defined tax structures.

\footnotetext{
${ }^{38}$ A positive correlation of intraregional business cycles could amplify, however, the regional business cycle relative to the rest of the world. This underscores the importance of exchange rate flexibility for the region as a whole against extra-regional trading partners.
} 
- Deficit financing may benefit from deeper regional capital markets as well as from any convergence to lower interest rates. This has been the experience in Europe, for example, in the run-up to the introduction of the euro. ${ }^{39}$ Much of that gain, however, has been traced back to a progressive elimination of exchange and inflation risk premia as prospects for a single currency strengthened and it is unlikely to be relevant in the Asian context for some time to come. ${ }^{40}$

- Intraregional financial integration and the expansion of vertical trade (i.e., in goods for further processing) will likely require a degree of tax harmonization. ${ }^{41}$ Capital and labor may become less nationally located and harder to tax, setting the stage for tax competition that, in a race to the bottom, may harm the provision of public goods. There may be a case for shifting the tax base to consumption, for example through more widespread reliance on a value added tax, with the additional benefit to limit trade distortions. ${ }^{42}$

\section{E. Integration and Macro Policies in the Long Run}

\section{What are the policy requirements for a monetary union?}

There is a broad recognition that a regional monetary union in Asia is a distant goal, at best. Asia's growing interconnectedness through trade in goods and capital is suggestive of the road taken by countries in continental Europe on the way to the Economic and Monetary Union. However, a realistic view needs to take into account the difficulties posed by Asia's cultural and political diversity, as well as lack of supra-national institutions and incomplete intraregional convergence.

- The Maastricht criteria provide reference points for assessing the region's degree of nominal convergence (Table). It is telling that, in 2005 no group of countries met all the Maastricht thresholds and most countries missed at least two (or more, if the debt ceilings were recalibrated to the Asian context).

\footnotetext{
${ }^{39}$ ECB Monthly Bulletin, February 2006.

${ }^{40}$ Emerging markets in Asia and elsewhere have reaped fiscal payoffs from global financial integration in terms of improved external financing. See Hauner and Kumar (2005).

${ }^{41}$ On the importance of vertical trade, Yam (2005) cites an HKMA's estimate of about 60 percent for the share of processing trade in total intra-Asia trade.

${ }^{42}$ Combes and Saadi-Sedik (2006) present evidence that trade-friendly fiscal structures can improve budgetary outcomes.
} 
Table III.1. Convergence in Asia: Maastricht Criteria

\begin{tabular}{lcccc}
\hline \hline & $\begin{array}{c}\text { Inflation } \\
\text { Rate }^{\mathrm{a}}\end{array}$ & $\begin{array}{c}\text { Interest } \\
\text { Rate }^{\mathrm{b}}\end{array}$ & $\begin{array}{c}\text { Fiscal } \\
\text { Balance }^{\mathrm{c}}\end{array}$ & \begin{tabular}{c} 
Gross $_{\text {Debt }^{\mathrm{a}}}$ \\
\hline Australia
\end{tabular} \\
Cambodia & $\mathbf{2 . 7}$ & $\mathbf{5 . 3}$ & 0.8 & 10.7 \\
China & $\mathbf{5 . 8}$ & $\ldots$ & $\mathbf{3 . 1}$ & 41.4 \\
Hong Kong SAR & 1.8 & 2.8 & -1.3 & 19.3 \\
India & 1.1 & 3.6 & 0.3 & 1.9 \\
Indonesia & $\mathbf{4 . 3}$ & $\mathbf{6 . 6}$ & $\mathbf{- 7 . 5}$ & $\mathbf{8 3 . 8}$ \\
Japan & $\mathbf{1 0 . 5}$ & $\mathbf{1 3 . 0}$ & 0.4 & 47.7 \\
Korea, Rep. Of & -0.3 & 1.4 & $\mathbf{- 5 . 8}$ & $\mathbf{1 7 5 . 5}$ \\
Malaysia & $\mathbf{2 . 7}$ & 3.5 & -0.8 & 32.0 \\
New Zealand & $\mathbf{3 . 0}$ & 3.6 & $\mathbf{- 3 . 6}$ & 45.4 \\
Philippines & $\mathbf{3 . 0}$ & $\mathbf{6 . 0}$ & 3.1 & 22.2 \\
Singapore & $\mathbf{7 . 6}$ & $\mathbf{1 0 . 9}$ & -1.9 & $\mathbf{6 6 . 9}$ \\
Thailand & 0.5 & 3.4 & 6.0 & $\ldots$ \\
Vietnam & $\mathbf{4 . 5}$ & $\mathbf{5 . 0}$ & 0.1 & 47.4 \\
\hline \hline
\end{tabular}

Note: Numbers in bold type exceed the reference values set out in the Maastricht Treaty.

a/ The criterion for compliance is obtained by taking the average for the three countries with the lowest inflation rates and adding 1.5.

$\mathrm{b} /$ The criterion for compliance is obtained by taking the average for the three countries with the lowest inflation rates and adding 2 percent margin allowed by the treaty.

$\mathrm{c} /$ The reference value is -3 percent of GDP.

$\mathrm{d} /$ The reference value is 60 percent of GDP.

- Convergence of production and economic structures is even more elusive, suggesting a vulnerability to country specific shocks that a monetary policy cast from a region-wide perspective could not counter. ${ }^{43}$

Policies can foster the convergence needed for a workable monetary union. ${ }^{44}$ At the most basic level, there is the need to get the macroeconomic framework right. Domestic stability and growth must be secured through flexible, transparent, market-based economic systems supported by responsible monetary, fiscal, and financial frameworks. In particular:

- Sound fiscal policies make for stronger economic performance which will ease the transition to - and the operation of - a monetary union. Fiscal prudence would also build the margin for maneuver to address country-specific shocks.

- A monetary policy firmly geared to price stability can lock in a history of low and stable inflation needed to back the eventual adoption of (irrevocably) fixed exchange rates

\footnotetext{
${ }^{43}$ The ratio of the highest to the lowest per capita income (at purchasing power exchange rates) was about four in Europe at the time the euro was introduced. In Asia (inclusive of industrial countries), it is now about 14. On the other hand, real convergence could be facilitated by the adoption of a common currency and economic heterogeneity should not necessarily undermine prospects for monetary unification (Eichengreen, 2004).

${ }^{44}$ Yam (2005) points to other technical issues (the choice of a regional anchor currency, mechanisms for central bank accountability, and interim exchange rate regimes) that, like lack of convergence, get in a way of a fast transition to a monetary union.
} 
among participating countries. Exchange rate flexibility in the transition to monetary unification will continue to provide the supporting exchange rate regime.

- Regulatory harmonization and shared governance practices can foster convergence of financial structures. Financial market reforms may in many instances help a move to greater exchange rate flexibility. Strengthened supervisory and prudential systems will also pave the way for greater capital account openness.

- Finally, an improved intraregional policy dialog and more effective mechanisms of regional surveillance will facilitate policy coordination and a greater focus on common goals. Further integration of the markets for good and services, and in capital and labor, will result.

\section{F. Concluding Remarks}

This paper has reviewed some of the policy implications of deepening economic integration within a region. It has highlighted for discussion mainstream views in the economic profession. There are other voices, though. For example, it has been argued that intraregional rigidity of exchange rate's has been key to Asia's stunning growth over the last three decades and should continue to be considered as a viable policy framework. ${ }^{45}$ This view represents, however, the opinion of a small, if influential minority. In a world where high capital mobility opens the door to financial contagion, it is difficult to make a convincing case for rigidly fixed exchange rate systems, unless a credible currency board or extensive capital controls are in place. Ultimately, the case for flexible, but judiciously managed exchange rates is perhaps that for a framework providing what Alan Greenspan has called "policy insurance" against undesirable economic outcomes.

There is perhaps a wider consensus on the choice of a viable monetary framework to accompany a shift to greater flexibility in the exchange rate system. The likely instability of money demand in economies undergoing far-reaching structural changes rules out, in most cases, alternatives such as targeting some money aggregates. There is a range of views, however, as to how the pursuit of price stability can be made operational. Some countries have opted for inflation targeting in different forms; others have chosen frameworks that leave more room for a flexible response to shocks to prices and output.

This overview of the implications of economic and financial integration for macroeconomic policies clearly brings out an overarching theme. There is no inherent tension between desirable policies in an increasingly integrated region and the policies to support economic resilience and dynamism in any one country, irrespective of regional trends. Asian countries are well advised to move toward greater policy transparency, stronger financial markets and institutions, and a multilateral policy dialog that favors cooperation and knowledge sharing. Policy frameworks that hold out the hope of fostering regional — indeed, global — integration are also the ones that promise stronger economic performances. National interests and regional interest seem inextricably bound together.

${ }^{45}$ MacKinnon (2001), for example. 


\section{References}

Combes Jean-Louis, and Tashin Saadi-Sedic 2006: "Does Trade Openness Influence Budget Deficits in Developing Countries?" IMF Working Paper 06/3 (Washington: International Monetary Fund).

Dammers, Clifford, and Robert N. McCauley, 2006, "Basket Weaving: the Euromarket Experience with Basket Currency Bonds", BIS Quarterly Review, Bank for International Settlements (March).

De Brower, Gordon, 2002, Does a Formal Common Basket Peg in East Asia Make Economic Sense? in Financial Markets and Policies in East Asia, London.

Dees, Stéphane, 2001, The Real Exchange Rate and Types of Trade”, Manuscript 2001.

Eichengreen, Barry, 2001 "Hanging Together? On Monetary and Financial Cooperation in Asia," http://elsa.berkeley.edu/users/eichengr/research.html

_ 2004, "Real and Pseudo Preconditions for an Asian Monetary Union," available on the Web at http://elsa.berkeley.edu/users/eichengr/research.html

— , 2005, "The Parallel Currency Approach to Asian Monetary Integration," available on the Web at http://elsa.berkeley.edu/users/eichengr/research.html

European Central Bank, ECB Monthly Bulletin, 2006, February, pp..

Hauner, David, and Manmohan Kumar, 2005 "Financial Globalization and Fiscal Performance in Emerging Markets," IMF Working Paper 05/212 (Washington: International Monetary Fund).

Kamada, Koichiro, and Izumi Takagawa, 2005, "Policy Coordination in East Asia and Across the Pacific, Bank of Japan Working Paper Series, No. 05-E-4.

McCauley, Robert N., 2001, "Setting Monetary Policy in East Asia: Goals, Developments and Institutions," in Gruen D. W. and J. Simon (Eds.), Future Directions for Monetary Policies in East Asia, Reserve Bank of Australia, Sydney.

McKinnon, Ronald, 2001, "After the Crisis, the East Asian Dollar Resurrected: An Interpretation of High-Frequency Exchange Rate Pegging" in Rethinking the East Asian Miracle ed. by Joseph E. Stiglitz and Shahid Yusuf, (New York: Oxford University Press).

Williamson, John, 1999, The case for a Common basket Peg for East Asian Currencies" in Exchange Rate Policies in Emerging Asian Countries, ed. by S. Collignon, J. PisaniFerry, and Y.C. Park (London). 
— 2005, "A Currency Basket for East Asia, not Just China” Policy Brief in International Economics, Institute for International Economics.

Yam, Joseph, 2004, "Speech at the International Center for Banking and Monetary Studies, November.

, 2005, "The Euro: a Stabilizing Factor of the International Monetary System. Can the Euro be a Benchmark for Asian Monetary Cooperation?" 
Figure III.2. Selected Indicators of Asia's Integration

Business cycles have become more correlated...

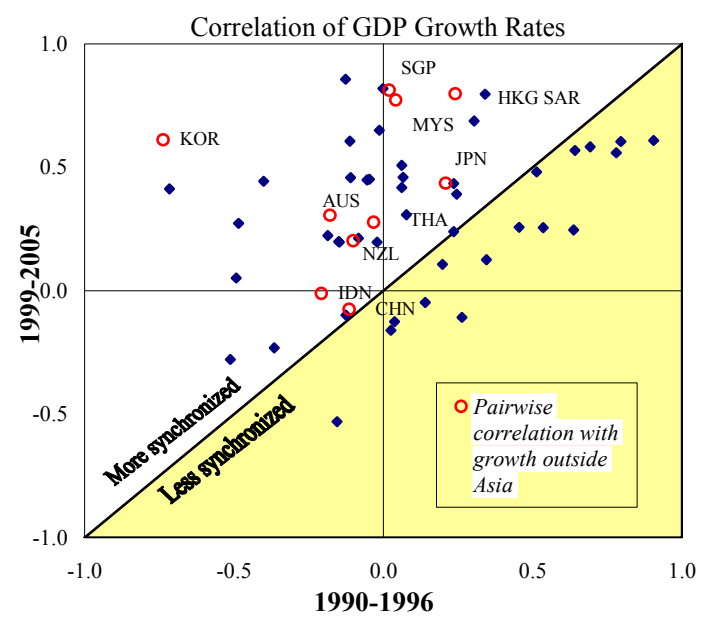

The dispersion of regional interest rates has fallen...

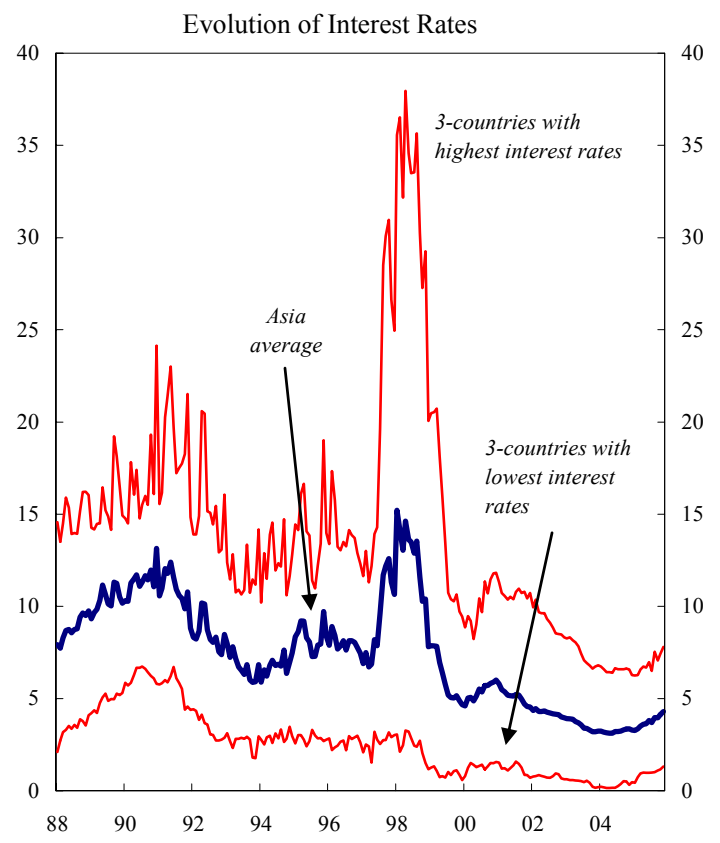

...as have stock market returns.

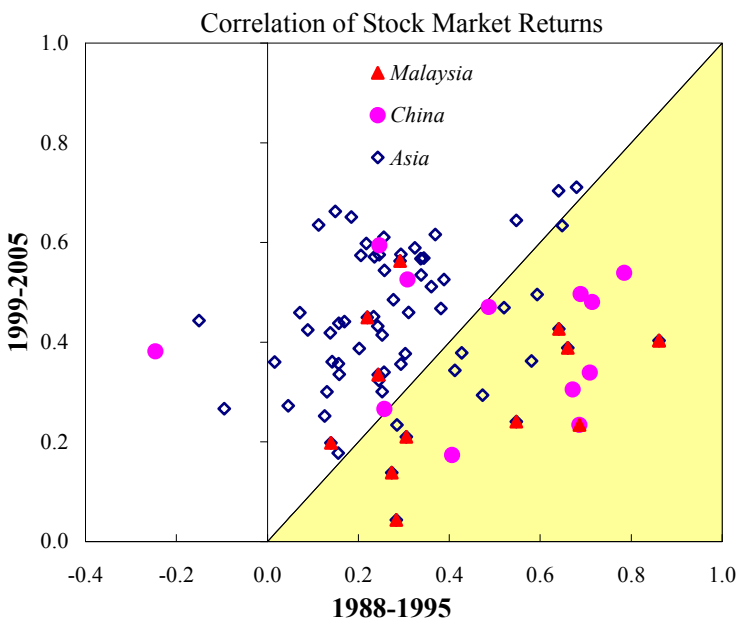

... as has that of inflation rate.

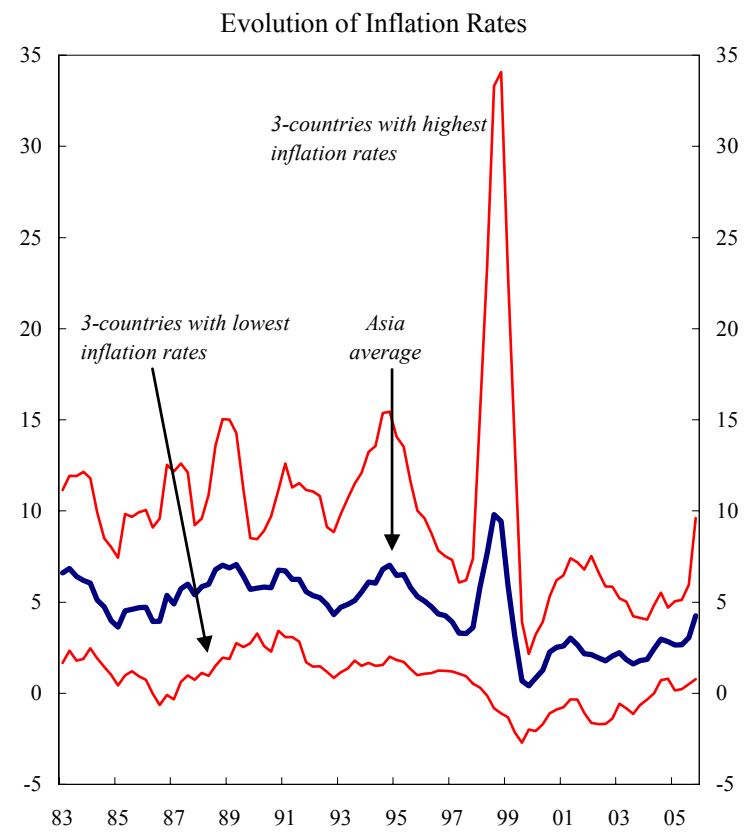

